\title{
Review
}

\section{Development of Responsive Lanthanide-Based Magnetic Resonance Imaging and Luminescent Probes for Biological Applications}

\author{
Kenjiro HANAOKA \\ Graduate School of Pharmaceutical Sciences, The University of Tokyo; \\ 7-3-1 Hongo, Bunkyo-ku, Tokyo 113-0033, Japan. \\ Received July 2, 2010
}

\begin{abstract}
Lanthanide complexes have unique chemical characteristics compared with typical organic complexes, and have recently attracted much interest because of the expanding need for new bioanalytical sensors. For example, magnetic resonance imaging (MRI) permits noninvasive three-dimensional imaging inside opaque organisms, and gadolinium ion $\left(\mathrm{Gd}^{3+}\right)$ complexes have become important tools as MRI contrast agents. However, most of them are nonspecific, and report solely on anatomy. Therefore, responsive MRI contrast agents, so-called "smart" MRI contrast agents whose ability to relax water protons is greatly enhanced by recognition of a particular biomolecule, have great potential for elucidating biological phenomena. On the other hand, lanthanide complexes such as europium $\left(\mathrm{Eu}^{3+}\right)$ and terbium $\left(\mathrm{Tb}^{3+}\right)$ complexes have excellent luminescence properties for biological applications, i.e., long luminescence lifetime of the order of milliseconds and a large Stoke's shift of $>200 \mathrm{~nm}$. Their long-lived luminescence is especially suitable for time-resolved measurements, because the interference from short-lived background fluorescence and scattered light rapidly decays to a negligible level after a pulse of excitation light is applied, and the emitted light can be collected after an appropriate delay time. These luminescent lanthanide complexes have already found commercial use as highly sensitive luminescent probes in heterogeneous and homogeneous assays. This paper reviews our research on the design and synthesis of responsive lanthanide-based MRI and luminescent probes for advanced bioimaging.
\end{abstract}

Key words sensor; bioimaging; lanthanide; magnetic resonance imaging; luminescence

\section{Introduction}

The lanthanides present various unique chemical properties that are favorable for both biological and materials research, and interest in their applications is increasing. ${ }^{1,2)}$ Lanthanide-based probes, especially responsive lanthanide probes intended for bioassay and bioimaging, are new players in these areas, and offer many advantages over typical organic molecules. ${ }^{3-5)}$ This paper reviews our research on the development of responsive lanthanide-based magnetic resonance imaging (MRI) and luminescent probes for biological applications.

\footnotetext{
Responsive Gadolinium $\left(\mathrm{Gd}^{3+}\right)$-Based MRI Contrast Agents for Bioimaging

Light-based microscope imaging techniques with fluorescent dyes are limited by photobleaching of the dyes and by light scattering by cells within $100 \mu \mathrm{m}$ of the surface. MRI can overcome these problems, and is especially useful for imaging inside intact, opaque organisms. ${ }^{6,7)} \mathrm{MR}$ images are based on topological representations of NMR parameters, and their contrast is determined not only by the complex interplay of endogenous factors $\left(T_{1}, T_{2}\right.$, and proton density), but also by various instrumental parameters. The contrast of MR images can be further enhanced by the use of MRI contrast agents, which act by enhancing the proton relaxation
}

rates in the tissues to which they are distributed. $\mathrm{Gd}^{3+}$ complexes, which are paramagnetic, are frequently chosen as MRI contrast agents, and these complexes enhance the $T_{1}$ (spin-lattice) and $T_{2}$ (spin-spin) relaxation rates of water protons in the proximity of the paramagnetic center, $\left.\mathrm{Gd}^{3+} .8-10\right)$ In $\mathrm{Gd}^{3+}$-based MRI contrast agents, chelation of $\mathrm{Gd}^{3+}$ is required for safety reasons: dissociation of $\mathrm{Gd}^{3+}$ from a MRI contrast agent is undesirable, as both the free metal and unchelated ligands are generally more toxic than the complex itself, and commonly used MRI contrast agents are mainly extracellular agents with nonspecific biodistribution. However, it is possible to develop $\mathrm{Gd}^{3+}$ complexes with various functions by means of appropriate ligand design for $\mathrm{Gd}^{3+}$. For example, some bioactivated MRI contrast agents, whose ability to relax water protons is greatly enhanced by recognition of a biomolecule, have been reported for monitoring of enzyme activity, $\mathrm{Ca}^{2+}, \mathrm{pH}, p\left(\mathrm{O}_{2}\right)$, etc. ${ }^{11-15)}$ These MRI contrast agents induce a change in the water proton relaxation time $\left(T_{1}\right.$ or $\left.T_{2}\right)$ in response to the presence of the target biomolecule.

The design of MRI contrast agents requires an understanding of the factors which determine the relaxation enhancement of the tissue protons. In an aqueous solution of $\mathrm{Gd}^{3+}$ complexes, there are three main contributions to relaxation 
enhancement of the solvent water protons which are propagated to the bulk through the exchange of the water molecules dipolarly coupled to $\mathrm{Gd}^{3+}$, i.e., water molecules that are directly coordinated to $\mathrm{Gd}^{3+}$ (inner sphere), those that belong to a second coordination sphere, and those that simply diffuse at the surface of the $\mathrm{Gd}^{3+}$ complex (outer sphere) (Fig. 1). Prototropic exchange is involved in the transmission of the magnetic interaction, and this may involve water protons in the inner or second coordination sphere or other exchangeable protons on the ligand. Therefore, the contrast of MR images can be modulated by appropriate design of $\mathrm{Gd}^{3+}$ complexes.

Firstly, focusing on water molecules in the inner sphere, several $\mathrm{Gd}^{3+}$-based bioactivated MRI contrast agents have been reported for monitoring enzyme activity, $\mathrm{Ca}^{2+}$, etc. ${ }^{11,12)}$ These MRI agents showed a change in the relaxation rate in the presence of biomolecules owing to modulation of the accessibility of water molecules to the chelated $\mathrm{Gd}^{3+}$ ion. For example, Meade and co-workers developed the bioactivated MRI contrast agent, EgadMe, which reports on $\beta$-galactosidase activity to image the expression of a transgene. ${ }^{11)} \beta$ Galactosidase is a commonly used gene expression marker, i.e., gene expression is monitored by introducing a marker gene, lacZ, to follow the regulation of a gene of interest, because it can easily be assayed and is not normally expressed in most mammalian tissues or cells. ${ }^{16-18)}$ This agent has been used to monitor gene expression in Xenopus laevis in vivo.

We also developed a novel zinc ion $\left(\mathrm{Zn}^{2+}\right)$-sensitive MRI contrast agent, the $\mathrm{Gd}^{3+}$ diethylenetriaminepentaacetic acid (DTPA) bisamide complex 1 (Fig. 2). ${ }^{19)} \mathrm{Zn}^{2+}$ is the second most abundant heavy metal ion after iron in the human body,

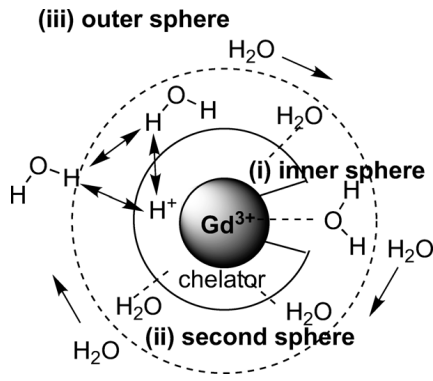

Fig. 1. The Relaxivity of a $\mathrm{Gd}^{3+}$ Complex Is Governed by the Dipolar Interaction between the Metal Center and the Proximate Water Protons

The propagation of the paramagnetic effect may occur through (i) exchange of the inner-sphere water protons; (ii) exchange of water molecules hydrogen-bonded at the $\mathrm{Gd}^{3+}$ complex surface and exchange of mobile hydrogens on the ligand; (iii) diffusion around the $\mathrm{Gd}^{3+}$ complex of the outer-sphere water molecules. and it is also an essential component of many enzymes, transcription factors, and synaptic vesicles in excitatory nerve terminals. ${ }^{20-22)}$ Recently, $\mathrm{Zn}^{2+}$ has been reported to play important roles in regulating synaptic transmission and cell death. ${ }^{23)}$ Therefore, imaging of chelatable $\mathrm{Zn}^{2+}$ in the extraand intracellular environments is of interest. Compound $\mathbf{1}$ was designed on the basis that $N, N, N^{\prime}, N^{\prime}$-tetrakis(2-pyridylmethyl)ethylenediamine (TPEN) readily complexes with $\mathrm{Zn}^{2+}$, but hardly complexes with $\mathrm{Ca}^{2+}$ or $\mathrm{Mg}^{2+} \cdot{ }^{24,25)}$ In characterizing 1, we observed that the water proton $r_{1}$ relaxivity of 1 showed an unusual $\mathrm{Zn}^{2+}$ dependence (Fig. 3). The longitudinal relaxivity value $r_{1}$ refers to the amount of increase in $1 / T_{1}$ per millimolar concentration of agent (often given as per $\mathrm{mm} \mathrm{Gd}) .{ }^{6}$ The observed longitudinal relaxation rate $\left(1 / T_{1}\right)_{\mathrm{obs}}$ of the solvent water protons is known to depend on the con-
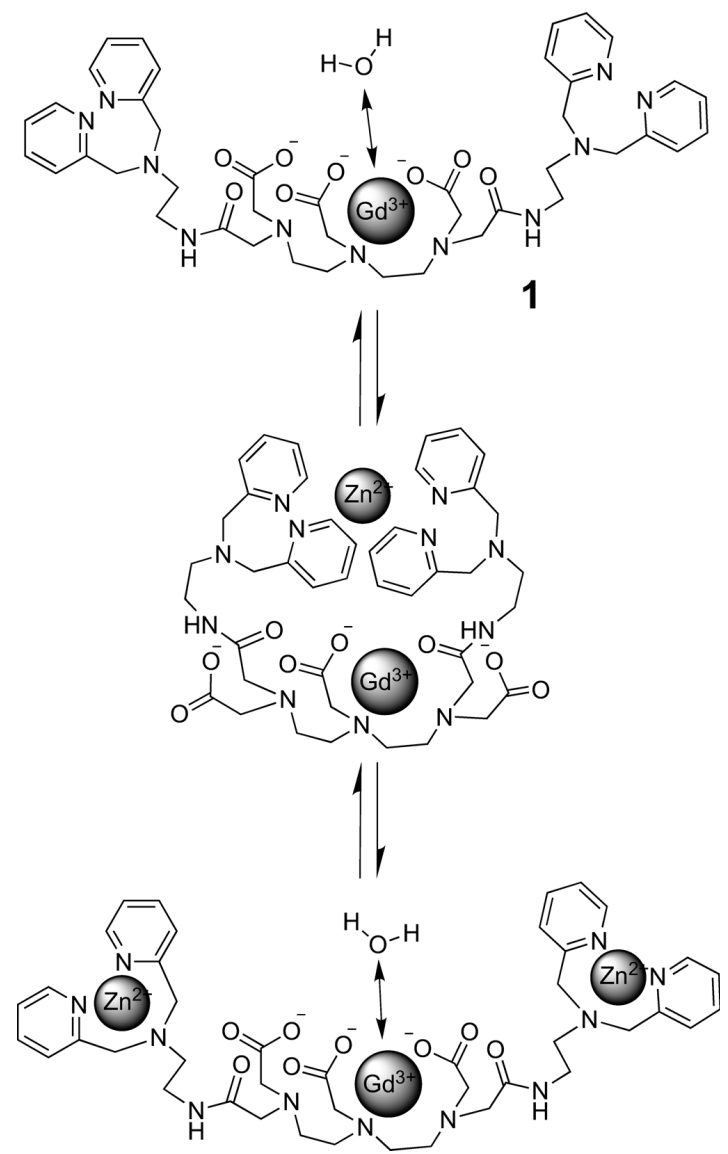

Fig. 2. Schematic Representation of a Novel $\mathrm{Zn}^{2+}$-Sensitive MRI Contrast Agent, 1, Showing the Proposed Conformational Change in the Presence and Absence of $\mathrm{Zn}^{2+}$

Kenjiro Hanaoka is currently an Assistant Professor (Lecturer) at Graduate School of Pharmaceutical Sciences, the University of Tokyo. He was born in Tokyo, Japan, in 1977 and received the B.S. in 2000 from the Faculty of Pharmaceutical Sciences, the University of Tokyo, and the M.S. in 2002 and the Ph.D. in 2005 from Graduate School of Pharmaceutical Sciences of the University of Tokyo under the direction of Professor Tetsuo Nagano. During 2005-2007, he was a JSPS research fellow, and also worked with Professor Thomas Kodadek at University of Texas Southwestern Medical Center. He became an Assistant Professor at Graduate School of Pharmaceutical Sciences, the University of Tokyo in 2007, and was promoted to an Assistant Professor (Lecturer) in 2010. He received the Pharmaceutical Society of Japan Award for Young Scientists in 2010. His research interests are in the development and applications of bioimaging probes.

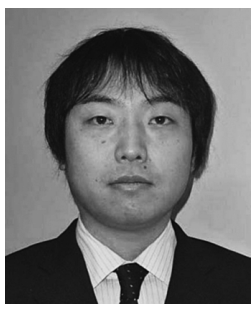

Kenjiro Hanaoka 


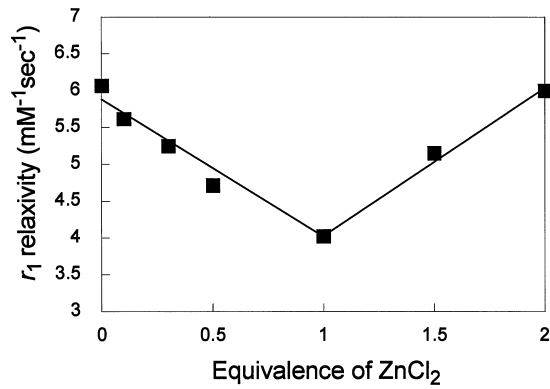

Fig. 3. The Water Proton $r_{1}$ Relaxivity of $\mathbf{1}$ at $\mathrm{pH} 8.0,25^{\circ} \mathrm{C}$ in the Presence of Various Concentrations of $\mathrm{Zn}^{2+}: 0,0.1,0.3,0.5,1.0,1.5$ and $2.0 \mathrm{eq}$

centration of $\mathrm{Gd}^{3+}$ according to Eq. 1.

$$
\left(1 / T_{1}\right)_{\mathrm{obs}}=\left(1 / T_{1}\right)_{\mathrm{d}}+r_{1} \times\left[\mathrm{Gd}^{3+}\right]
$$

where $\left(1 / T_{1}\right)_{\text {obs }}$ is the observed relaxation rate of water protons in the presence of $\mathrm{Gd}^{3+}$, and $\left(1 / T_{1}\right)_{\mathrm{d}}$ is the diamagnetic relaxation rate of water protons in the absence of $\mathrm{Gd}^{3+}$. $\left[\mathrm{Gd}^{3+}\right]$ is the millimolar concentration of $\mathrm{Gd}^{3+}$. Therefore, a plot of $\left(1 / T_{1}\right)_{\mathrm{obs}}$ versus $\left[\mathrm{Gd}^{3+}\right]$ would give the $r_{1}$ relaxivity as the slope, and the $r_{1}$ relaxivity, normally expressed in units of $\mathrm{mm}^{-1} \mathrm{~s}^{-1}$, reflects the relaxation enhancement ability of the $\mathrm{Gd}^{3+}$ complex. The $r_{1}$ relaxivity of a solution of $\mathbf{1}$ decreased dose-dependently between 0 and $1.0 \mathrm{eq} \mathrm{Zn}^{2+}$, reaching a minimum at $1.0 \mathrm{eq} \mathrm{Zn}^{2+}$ to $\mathbf{1}$, and then increasing dose-dependently between 1.0 and 2.0 eq. The $r_{1}$ relaxivity of 1 decreased approximately $33 \%$ when $\mathrm{Zn}^{2+}$ (1.0 eq to $\mathbf{1}$ ) was added to a $\mathrm{Zn}^{2+}$-free solution. The change in $T_{1}$ generated by the addition of $\mathrm{Zn}^{2+}$ (1.0 eq to 1$)$ can be visualized in MR images of a solution of 1 (Fig. 4). The reason for this is considered to be as follows. When the $\mathrm{Zn}^{2+}-\mathbf{1}$ molar ratio is between $0: 1$ and $1: 1, \mathrm{Zn}^{2+}$ and 1 form a $1: 1$ complex. On the other hand, when the $\mathrm{Zn}^{2+}-1$ molar ratio exceeds one, $\mathrm{Zn}^{2+}$ and $\mathbf{1}$ form a 2: 1 complex. We hypothesize that 1 in the $\mathrm{Zn}^{2+}-11: 1 \mathrm{com}-$ plex has fewer water molecules binding directly to $\mathrm{Gd}^{3+}$ as compared with $\mathbf{1}$ in a $\mathrm{Zn}^{2+}$-free solution. This can be understood in terms of the $\mathrm{Zn}^{2+}$ coordination geometry, which is proposed to be as shown in Fig. 2. In the $\mathrm{Zn}^{2+}-12: 1 \mathrm{com}-$ plex, 1 has the same number of water molecules binding directly to $\mathrm{Gd}^{3+}$ as $\mathbf{1}$ in a $\mathrm{Zn}^{2+}$-free solution, because the second $\mathrm{Zn}^{2+}$ opens up the water-accessible space on the surface of $\mathrm{Gd}^{3+}$. This hypothesis was supported by measurements of the UV-visible spectra and the coldspray ionization (CSI) mass spectra. ${ }^{26-28)}$ Thus, these $\mathrm{Zn}^{2+}$-chelating characteristics of $\mathbf{1}$ seem to modulate access of water molecules to the $\mathrm{Gd}^{3+}$ ion. However, the behavior of the $r_{1}$ relaxivity of a solution of $\mathbf{1}$ is problematic, because the response above $1.0 \mathrm{eq}$ of $\mathrm{Zn}^{2+}$ is also augmented and hence not monotonic. Briefly, for example, one cannot distinguish the $r_{1}$ values of solutions of 1 containing 0.3 and 1.5 eq of $\mathrm{Zn}^{2+}$.

The amides of compound $\mathbf{1}$ have relatively weak chelating ability, and moreover, we hypothesized that compound $\mathbf{1}$ would suffer from a steric repulsion effect of the four pyridines in the $\mathrm{Zn}^{2+}-\mathbf{1} 1: 1$ complex (Fig. 2). Therefore, we designed and synthesized the $\mathrm{Gd}^{3+}$ DTPA-bisamide complex $\mathbf{2}$, which is a derivative of $\mathbf{1}$, as a novel $\mathrm{Zn}^{2+}$-sensitive MRI contrast agent (Fig. 5). ${ }^{29)}$ The reasoning behind the design of 2 is as follows. The carboxylate substituent chelates $\mathrm{Zn}^{2+}$ strongly, and has a smaller steric repulsion than pyridyl. So,

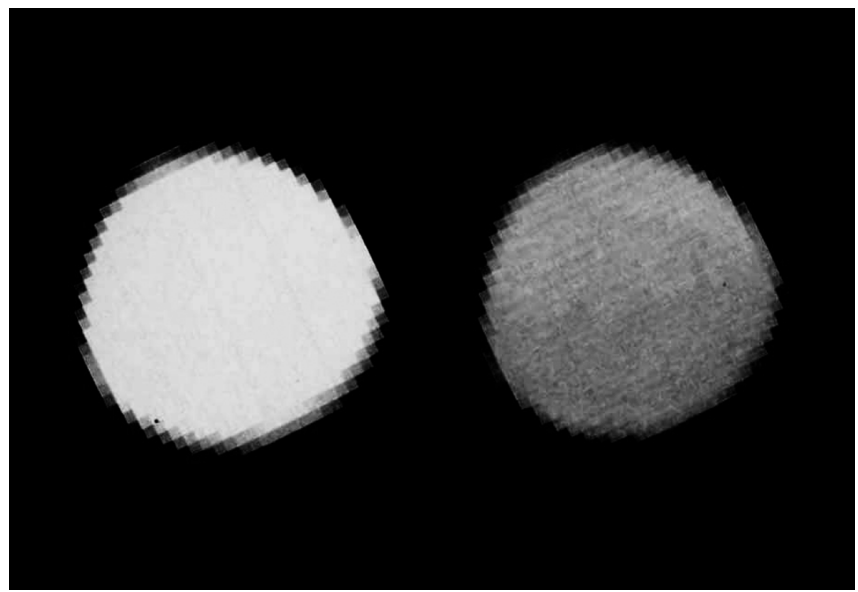

Fig. 4. $T_{1}$-Weighted MR Image of Solutions of $1(0.25 \mathrm{~mm})$ in the Presence (Right) and Absence (Left) of $\mathrm{Zn}^{2+}(0.25 \mathrm{~mm})$

Both samples were dissolved in distilled water in small vials, and imaged with a Varian INOVA200 (4.7 T)
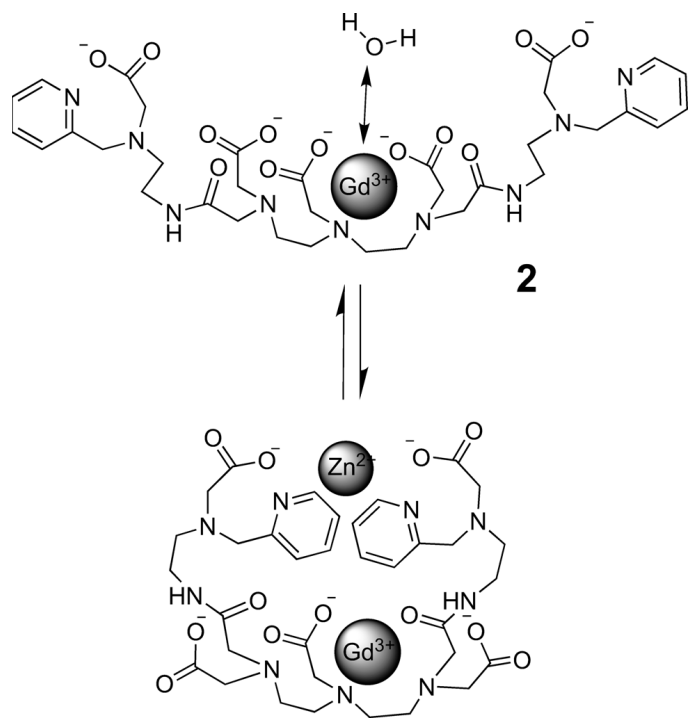

Fig. 5. Schematic Representation of a Novel $\mathrm{Zn}^{2+}$-Sensitive MRI Contrast Agent, 2, Showing the Proposed Conformational Change in the Presence and Absence of $\mathrm{Zn}^{2+}$, with a Monotonic Change of the $r_{1}$ Relaxivity

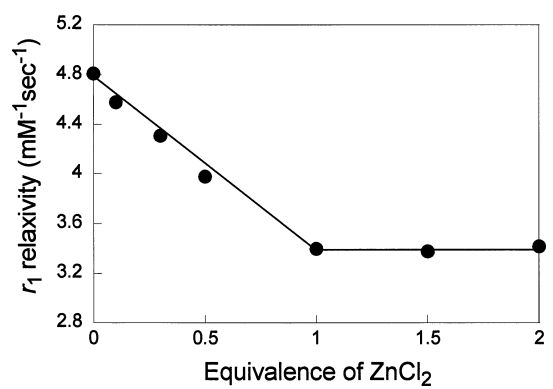

Fig. 6. The Water Proton $r_{1}$ Relaxivities of 2 Were Measured in $25 \mathrm{~mm}$ KMOPS Buffer ( $\mathrm{pH} 7.20)$ in the Presence of Various Concentrations of $\mathrm{Zn}^{2+}: 0,0.1,0.3,0.5,1.0,1.5$ and $2.0 \mathrm{eq}$

we expected to obtain a monotonic change with this stronger chelator. Indeed, in characterizing $\mathbf{2}$, we observed that the water proton $r_{1}$ relaxivity of a solution of $\mathbf{2}$ had a monotonic $\mathrm{Zn}^{2+}$ dependence (Fig. 6). The $r_{1}$ relaxivity decreased dose- 
dependently between 0 and 1.0 eq $\mathrm{Zn}^{2+}$, reaching a minimum at $1.0 \mathrm{eq} \mathrm{Zn}^{2+}$, then the $r_{1}$ relaxivity remained at a plateau with further increase of $\mathrm{Zn}^{2+}$. The $r_{1}$ relaxivity of $\mathbf{2}$ solution decreased approximately $30 \%$ when $1.0 \mathrm{eq}$ of $\mathrm{Zn}^{2+}$ added, and the change in $T_{1}$ generated by the addition of $\mathrm{Zn}^{2+}$ (1.0 eq to 2 ) could be visualized in MR images of a solution of 2 (Fig. 7). Moreover, there was no large effect of $\mathrm{H}^{+}$on the $r_{1}$ relaxivity between $\mathrm{pH} 6$ and 8 in the absence of $\mathrm{Zn}^{2+}$, and 2 also showed high selectivity for $\mathrm{Zn}^{2+}$ over $\mathrm{Ca}^{2+}$ and $\mathrm{Mg}^{2+}$. These characteristics of the complex are favorable for in vivo imaging of $\mathrm{Zn}^{2+}$ concentration changes by comparing the signal intensity decreases in a region of interest with and without various stimuli, given that the clearance of the agent itself should remain unchanged. These agents $(\mathbf{1}, \mathbf{2})$ are the first $\mathrm{Zn}^{2+}$-sensitive MRI contrast agents, and should be excellent candidates for incorporation into sensors designed for biological applications. Indeed, several $\mathrm{Zn}^{2+}$-sensitive MRI contrast agents have recently been reported. ${ }^{30-32)}$

Secondly, another possible approach for the development of responsive MRI contrast agents is the RIME (receptor-induced magnetization enhancement) approach. ${ }^{33-35)}$ The binding of a MRI contrast agent to a macromolecule substantially slows molecular rotation of the $\mathrm{Gd}^{3+}$ complex, resulting in an additional increase in the $r_{1}$ relaxivity through the rotational correlation time $\tau_{\mathrm{R}}{ }^{7)}$ In other words, when the $\mathrm{Gd}^{3+}$ complex binds to a macromolecule, the $\tau_{\mathrm{R}}$ increases from that of a small molecule to that of the protein, and the $r_{1}$ relaxivity increases. The slower the $\mathrm{Gd}^{3+}$ complex tumbles, the longer the $\tau_{\mathrm{R}}$, leading to faster relaxation rates and hence higher $r_{1}$ relaxivity. The length of $\tau_{\mathrm{R}}$ for small $\mathrm{Gd}^{3+}$ complexes is usually in the picosecond range (typically 50 $200 \mathrm{ps}$ ), whereas the $\tau_{\mathrm{R}}$ for a macromolecule such as albumin is in the nanosecond range $(c a .50 \mathrm{~ns}) .{ }^{36)}$ This phenomenon is known as RIME, and RIME agents have been reported for alkaline phosphatase and for carboxypeptidase B (part of the thrombin-activatable fibrinolysis inhibitor family), which regulate noncovalent binding of the agents to human serum albumin (HSA). ${ }^{37,38)}$ Another agent permitted the detection of yeast transcription repressor protein (Gal80) in MR images by utilizing a specific peptide-protein binding event, ${ }^{39}$ ) and efficient polymerization of $\mathrm{Gd}^{3+}$ complexes was also used to image the activity of myeloperoxidase (MPO). ${ }^{40}$

We developed a novel $\beta$-galactosidase-activated MRI contrast agent 3, which is a $\mathrm{Gd}^{3+}$ complex, by using the RIME approach (Fig. 8). ${ }^{41)}$ Compound $\mathbf{3}$ is composed of three moieties: 1) a masking group consisting of galactopyranose; 2)

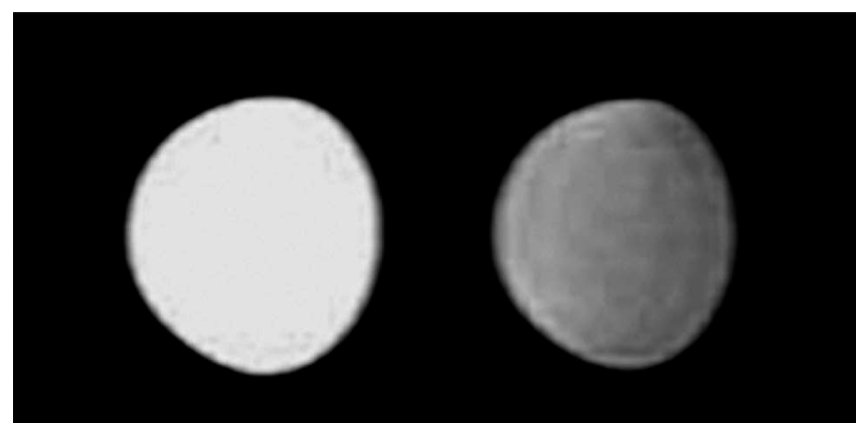

Fig. 7. $T_{1}$-Weighted MR Image of Solutions of $2(0.25 \mathrm{~mm})$ in the Presence (Right) and Absence (Left) of $\mathrm{Zn}^{2+}(0.25 \mathrm{~mm})$

Both samples were dissolved in distilled water in small vials, and imaged with a Varian INOVA200 (4.7 T) an albumin-binding moiety, the biphenyl group; 3) a MRI signal-generating moiety, which is a $\mathrm{Gd}^{3+}$ complex. The biphenyl group was selected as the albumin-binding group, because the biphenyl residue is known to possess high albumin binding affinity. ${ }^{6,38,42)}$ A substrate for $\beta$-galactosidase, galactopyranose, was used as a masking group, affording high hydrophilicity compared with the hydrophobicity of the biphenyl group. i.e., cleavage of the galactopyranose moiety from the aryl group of the $\mathrm{Gd}^{3+}$ complex increases the hydrophobicity of the aryl group, thereby increasing the HSA binding affinity. The greater binding of the $\mathrm{Gd}^{3+}$ complex to the macromolecule, HSA, increases the $r_{1}$ relaxivity. Thus, the $\mathrm{Gd}^{3+}$ complex 3 was designed to detect $\beta$-galactosidase activity through its conversion into 4 (Fig. 8). This newly synthesized compound 3 exhibited a $57 \%$ increase in the $r_{1}$ relaxivity in phosphate buffered saline (PBS) containing $4.5 \% \mathrm{w} / \mathrm{v}$ HSA in the presence of $\beta$-galactosidase. Moreover, the longitudinal relaxation times $T_{1}$ of $\mathbf{3}$ were measured in the presence of $\beta$-galactosidase or heat-inactivated $\beta$-galactosidase with $4.5 \% \mathrm{w} / \mathrm{v}$ HSA in PBS $(\mathrm{pH} 7.4)$ at $20 \mathrm{MHz}$ $(0.47 \mathrm{~T})$ at $37^{\circ} \mathrm{C}$ (Fig. 9). The value of $1 / T_{1}$ increased from 3.5 to $5.5 \mathrm{~s}^{-1}$ between 0 and $250 \mathrm{~min}$ in the presence of $\beta$ -
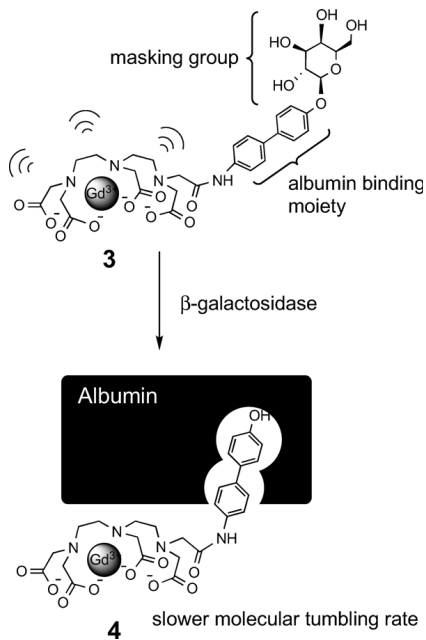

Fig. 8. The RIME Mechanism for the $\beta$-Galactosidase-Activated MRI Contrast Agent 3

In compound $\mathbf{3}, \mathrm{a} \mathrm{Gd}^{3+}$ complex is coupled to an albumin binding moiety that is masked by the galactopyranose residue. The galactopyranose residue of $\mathbf{3}$ is designed to be cleaved by $\beta$-galactosidase, transforming 3 to 4 , and this cleavage promotes albumin binding of the $\mathrm{Gd}^{3+}$ complex.

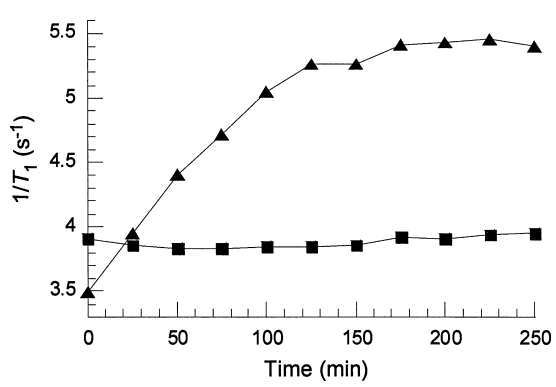

Fig. 9. Time Course of the $\beta$-Galactosidase-Induced (113 nm; Closed Triangle) and Heat-Inactivated $\beta$-Galactosidase-Induced (113 nm; Closed Square) Changes in the Value of $1 / T_{1}\left(\mathrm{~s}^{-1}\right)$, of a $0.5 \mathrm{~mm}$ Solutions of 3 at $20 \mathrm{MHz}, 37^{\circ} \mathrm{C}$ in PBS (pH 7.4) Containing $4.5 \%$ w/v Human Serum Albu$\min (\mathrm{HSA})$ 
galactosidase, while the value of $1 / T_{1}$ changed only slightly from 3.8 to $4.0 \mathrm{~s}^{-1}$ between 0 and $250 \mathrm{~min}$ on exposure to heat-inactivated $\beta$-galactosidase. On HPLC analysis, the $\mathrm{Gd}^{3+}$ complexes, 3 and $\mathbf{4}$, showed distinct retention times, and it was confirmed that $\mathbf{3}$ was converted into $\mathbf{4}$ in the presence of $\beta$-galactosidase, while essentially no change was observed upon the addition of heat-inactivated $\beta$-galactosidase. Thus, compound 3 exhibited a $\beta$-galactosidase-induced RIME effect, accompanying the removal of the galactopyranose residue of $\mathbf{3}$.

Thirdly, it is also possible to modulate prototropic exchange by utilizing pendant arms of ligands. Sherry and coworkers have developed a $\mathrm{pH}$-sensitive MRI contrast agent, which has the tetraamide-based ligand with extended phosphonate side chains with the intention of generating systems with specific ion-pairing capability. ${ }^{13)}$ In characterizing this MRI contrast agent, it was observed that the water proton $r_{1}$ relaxivity of the compound showed an unusual $\mathrm{pH}$ dependence, increasing between $\mathrm{pH} 4$ and 6 , reaching a maximum near $\mathrm{pH} 6$, gradually decreasing to a minimum near $\mathrm{pH} 8.5$, and then remaining relatively insensitive to $\mathrm{pH} 10.5$ before increasing once again at higher $\mathrm{pH}$ values.

\section{Future Challenges for Low-Molecular-Weight Gd ${ }^{3+}$ Com- plexes}

As mentioned above, MRI has become increasingly widely used for both experimental and clinical molecular imaging. However, simple low-molecular-weight $\mathrm{Gd}^{3+}$ complexes such as those currently used in clinical MRI have a significant problem, i.e., they are considered too insensitive for imaging applications. ${ }^{43,44)}$ For example, nowadays, there is great interest in the development of MRI contrast agents that can be targeted to specific biomolecules, and given the limited sensitivity of $T_{1}$-based agents such as $\mathrm{Gd}^{3+}$ complexes, a question arises as to whether or not biologically interesting molecules are present at a sufficiently high concentration to allow them to be visualized. ${ }^{45-58)}$ Therefore, we examined the detection limit of such $\mathrm{Gd}^{3+}$ complexes in a detection crodomains of high local concentration. ${ }^{59)}$ i.e., we examined how concentrations of anti-FLAG antibody could be imaged using a relatively simple, low-molecular-weight targeted consystem with molecules clustered together to form mi-

trast agent consisting of the FLAG-peptide linked to a $\mathrm{Gd}^{3+}$ complex, FLAG-peptide-GdDO3A conjugate 5 (Fig. 10). The anti-FLAG antibody had a high affinity for $\mathbf{5}$ $\left(K_{\mathrm{d}}=150 \mathrm{nM}\right)$, and the water proton $r_{1}$ relaxivity of $\mathbf{5}$ $\left(10.7 \mathrm{~mm}^{-1} \mathrm{~s}^{-1}\left(23 \mathrm{MHz}, 25^{\circ} \mathrm{C}\right)\right)$ increased approximately 1.6 fold when 5 was bound to the antibody. The detection limits of 5 in Tris-buffered saline (TBS) buffer and on the surface of anti-FLAG agarose gel beads at $9.4 \mathrm{~T}$ MRI were $9 \mu \mathrm{M}\left(=9 \mathrm{pmol} / \mathrm{mm}^{3}\right)$ and $4 \mu \mathrm{M}\left(=4 \mathrm{pmol} / \mathrm{mm}^{3}\right)$, respectively, as defined for a contrast-to-noise ratio of $3(3 \sigma) .{ }^{60)}$ Further, analytically, one can define the detection limit in terms of the smallest $T_{1}$ difference (of solvent versus solvent with agent) necessary to produce significant image contrast (Eq. 2), which in turn is proportional to $\left[\mathrm{Gd}^{3+}\right]_{\mathrm{DL}}$ at the detection limit times the $r_{1}$ relaxivity of the agent.

$$
1 / T_{1}-1 / T_{0}=\left(T_{1 \mathrm{P}}{ }^{-1}\right)_{\mathrm{DL}}=\left[\mathrm{Gd}^{3+}\right]_{\mathrm{DL}} \times r_{1}
$$

If one fixes $\left(T_{1 \mathrm{P}}{ }^{-1}\right)_{\mathrm{DL}}$ to the value determined experimentally, one can easily predict the lower detection limits of other $\mathrm{Gd}^{3+}$-based agents that may have even higher fully bound $r_{1}$ relaxivity values. The curve in Fig. 11 shows this prediction in graphical form. For a molecularly targeted agent consisting of a single $\mathrm{Gd}^{3+}$ ion with bound $r_{1}$ relaxivity of $100 \mathrm{mM}^{-1} \mathrm{~s}^{-1}$ or five $\mathrm{Gd}^{3+}$ complexes each with a bound $r_{1}$ relaxivity of $20 \mathrm{~mm}^{-1} \mathrm{~s}^{-1}$, the detection limit of a protein microdomain is approximately $690 \mathrm{~nm}$ using a $9.4 \mathrm{~T}$ spectrometer. It can be considered that cell surface receptors overexpressed on the surface of tumors might be present at a sufficiently high local concentration to be imaged by targeted low-molecular-weight $\mathrm{Gd}^{3+}$ complexes if their binding affinity and specificity were sufficient to allow enough of them to be clustered in such a microdomain. ${ }^{61)}$ Thus, our results and extrapolations suggest that MRI detection using low-molecular-weight targeted $T_{1}$ agents is not an unrealistic goal, and we should consider these detection limits of $\mathrm{Gd}^{3+}$ complexes in relation to the future development of in vivo responsive $\mathrm{Gd}^{3+}$-based MRI contrast agents.

\section{Responsive Lanthanide-Based Luminescent Probes for Bioimaging}

Fluorescence imaging is a powerful tool for the visualization of biomolecules in various biological environments, and

b)

c)

a)
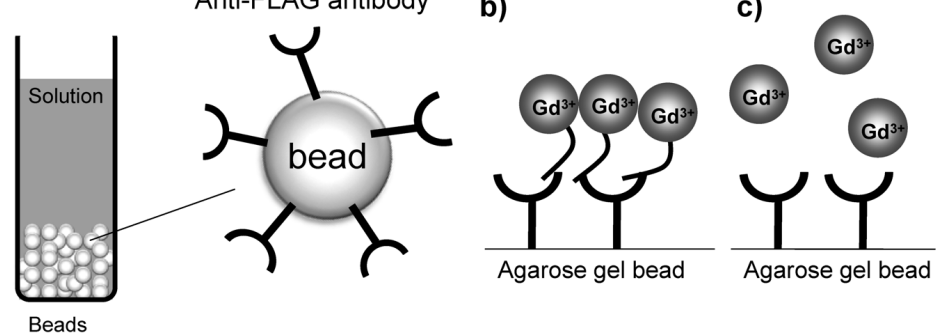

d)

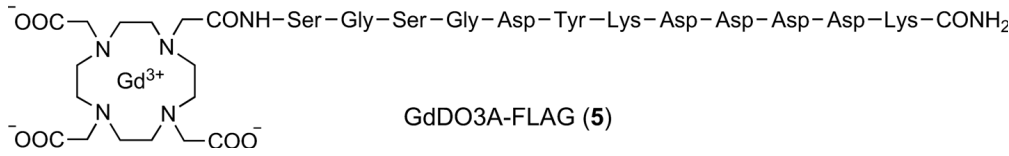

Fig. 10. Schematic Representation of the Model System

(a) Anti-FLAG M2-agarose affinity gel beads are used as a model of highly concentrated cell surface receptors. (b) Upon addition of a GdDO3A-FLAG conjugate 5, the probe is concentrated at the agarose gel bead surface. (c) Addition of nonspecific GdDTPA as a control. (d) Chemical structure of the GdDO3A-FLAG peptide conjugate 5. 
is important for elucidating biological functions. ${ }^{62,63)}$ Further, the development of new fluorescent dyes with improved photophysical properties, combined with technical progress in optical devices for fluorescence microscopy, will open the way to superior fluorescence imaging technologies. Usual time-resolved fluorescence microscopy exploits differences in fluorescence lifetimes of the order of nanoseconds to monitor target fluorescence, and this technique has been used to image interactions between proteins or protein phosphorylation by detecting fluorescence resonance energy transfer (FRET), and to report on the local environment of fluorophores, for example, local $\mathrm{pH}$, refractive index, ion or oxygen concentration. ${ }^{64)}$ We have developed a new system for time-resolved long-lived luminescence microscopy (TRLLM), which utilizes the extremely long luminescence lifetimes of luminescent lanthanide complexes, of the order of milliseconds. ${ }^{65)}$ TRLLM is expected to allow imaging with complete elimination of the short-lived background fluorescence, providing high signal-to-noise ratios, by the introduction of an appropriate delay time between the pulsed excitation light and measurement of the long-lived luminescence

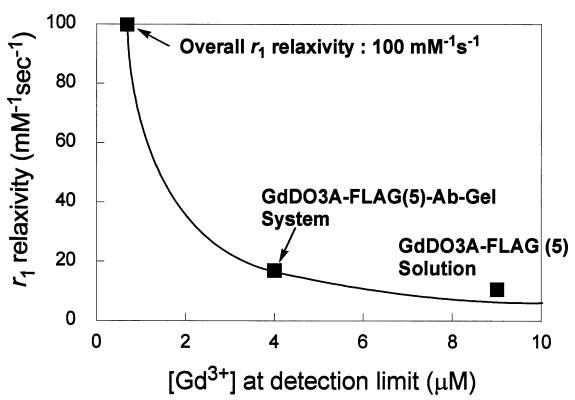

Fig. 11. Plot of $r_{1}$ Relaxivity versus the Detection Limit based Upon Eq. 2 The $\left(T_{1 \mathrm{p}}{ }^{-1}\right)_{\mathrm{DL}}=0.069 \mathrm{~s}^{-1}$ of the GdDO3A-FLAG peptide (5) bound to anti-FLAG gel beads (i.e., the GdDO3A-FLAG(5)-Ab-Gel system), with $r_{1}$ relaxivity $=17.2 \mathrm{~mm}^{-1} \mathrm{~s}^{-1}$ and $\left[\mathrm{Gd}^{3+}\right]$ at the detection limit $=4 \mu \mathrm{M}$, is constant for the curve. This constant corresponds to the smallest difference in $T_{1}$ that the MRI can discriminate under these imaging conditions. The values of $r_{1}$ relaxivity at the detection limits for GdDO3AFLAG(5)-Ab-Gel system $(4.0 \mu \mathrm{M})$, GdDO3A-FLAG (5) in solution $(9.0 \mu \mathrm{M})$, and the detection limit of hypothetical target agents with overall $r_{1}$ relaxivity of $100 \mathrm{~mm}^{-1} \mathrm{~s}^{-1}$ are shown. of the dye (Fig. 12). ${ }^{66-75)}$ Thus, this TRLLM imaging has very different characteristics from conventional timeresolved fluorescence imaging. A schematic of the TRLLM system, which was newly developed by us, is shown in Fig. 13. This system utilizes a conventional fluorescence microscopy system equipped with an image intensifier (I.I.) unit, xenon flash lamp and timing controller. Applications of mechanical choppers in TRLLM with long-lived luminescent dyes have been reported by some groups, ${ }^{66-73)}$ and other groups have employed an I.I. unit for the time-resolution. ${ }^{74,75)}$

New fluorescent dyes with long fluorescence lifetimes are needed for the TRLLM-based microscopic method. Luminescent lanthanide complexes, in particular complexes of europium and terbium trivalent ions $\left(\mathrm{Eu}^{3+}\right.$ and $\left.\mathrm{Tb}^{3+}\right)$, possess extremely long luminescence lifetimes of the order of milliseconds, whereas typical organic fluorescent compounds possess short fluorescence lifetimes in the nanosecond region. $^{76,77)}$ Further, luminescent lanthanide complexes are thought to be relatively insensitive to photobleaching and the generation of singlet oxygen compared with phosphorescent dyes. ${ }^{67)}$ For these reasons, luminescent lanthanide complexes have recently been exploited in various bioassays with time-

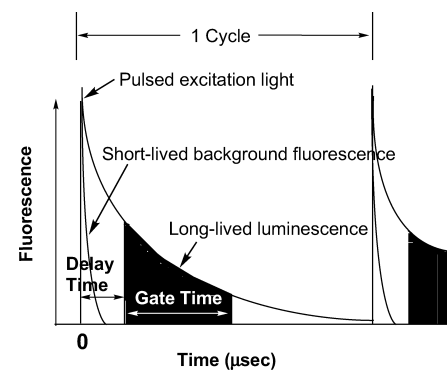

Fig. 12. Principle of Time-Resolved Long-Lived Luminescence Measurements

The short-lived background fluorescence decays to a negligible level during an appropriate delay time between a pulse of excitation light and the measurement of the long-lived luminescence. The period for which the fluorescence is measured is the gate time. The time-resolved long-lived luminescence measurement obviates interference from the short-lived background fluorescence.

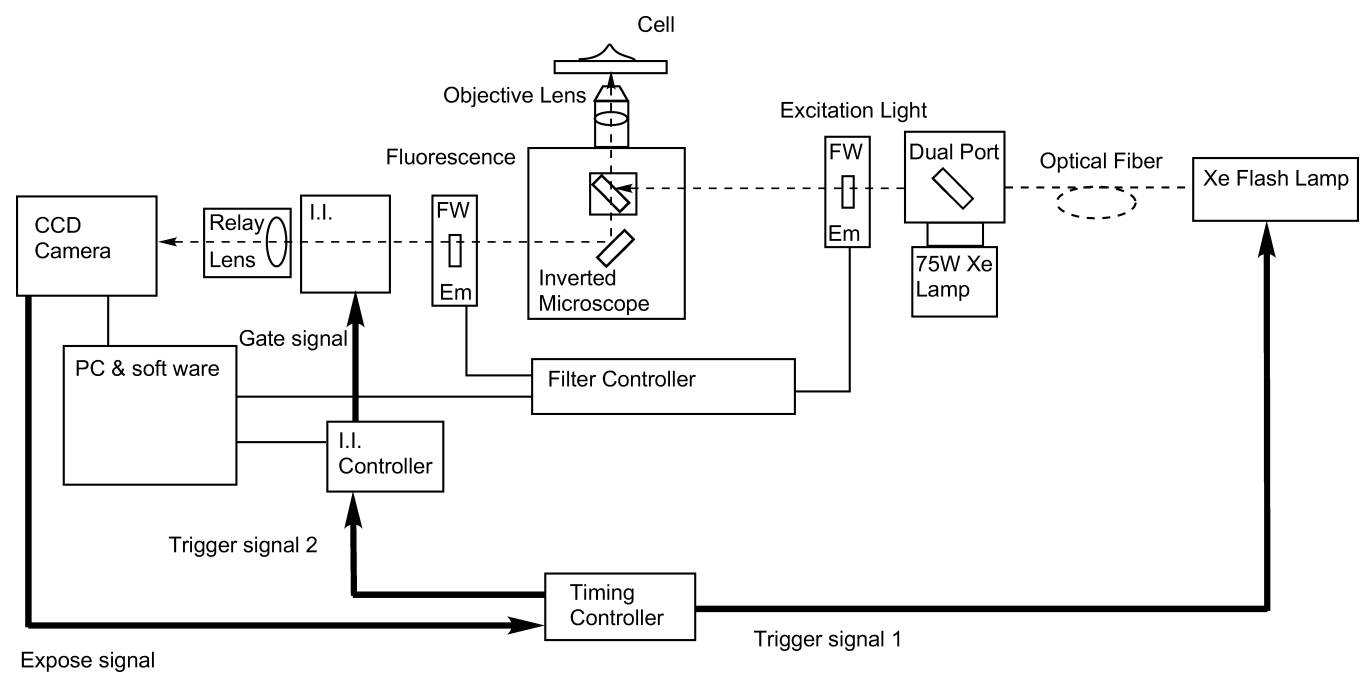

Fig. 13. Schematic Diagram of the Optical Apparatus Used for the TRLLM System

The excitation source is a xenon flash lamp. The excitation light passes through the excitation filter and is focused onto cells with dichroic mirrors. The emission light passes through the emission filter. The I.I. unit passes the long-lived luminescence to the CCD camera, controlling the delay time, the gate time, and the gain. The excitation and emission light can be easily selected by using appropriate excitation and emission filters. The image is recorded on the CCD camera, and then transferred to the computer for further processing with MetaFluor 6.1 software. 
gating in the fields of medicine, biotechnology, and biological science. ${ }^{78)}$ On the other hand, the lanthanide $\mathrm{f}-\mathrm{f}$ transitions have low absorbance, so a sensitizing chromophore covalently bound to the ligand is desirable for high luminescence (Fig. 14). ${ }^{79)}$ Absorption by the chromophore results in effective population of its triplet level, and efficient intramolecular energy transfer conveys the absorbance energy of the excited chromophore to a chelated lanthanide metal ion, which becomes excited to the emission state (Fig. 15). Therefore, proper chromophore design should afford luminescent lanthanide complexes which possess appropriate photochemical properties for TRLLM.

We examined the application of our newly synthesized luminescent $\mathrm{Eu}^{3+}$ complex 6, to conventional microscopy or TRLLM of cultured living HeLa cells (Fig. 16a). ${ }^{65)}$ The fluorescence microscope had an optical window centered at $617 \pm 37 \mathrm{~nm}$ for the emission due to $\mathrm{Eu}^{3+}$-based luminescence upon excitation at $360 \pm 40 \mathrm{~nm}$. The $\mathrm{Eu}^{3+}$ complex 6 was injected into cultured HeLa cells. In the prompt fluorescence images, the $\mathrm{Eu}^{3+}$ complex-injected cells were seen, together with the $\mathrm{Eu}^{3+}$ complex-noninjected cells which appeared owing to their weak autofluorescence (Fig. 16b). In the TRLLM images, the autofluorescence from the cells, which is short-lived, was gated out, allowing the $\mathrm{Eu}^{3+}$ complex-injected cells to be clearly distinguished (Fig. 16b).

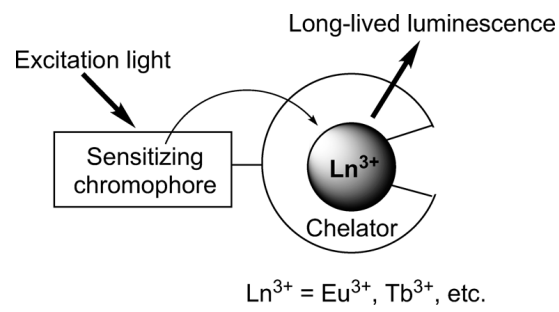

Fig. 14. Schematic View of a Sensitizing Chromophore Incorporated into a Lanthanide Emitter

Efficient intramolecular energy transfer should occur from the excited chromophore to the proximate lanthanide ion after excitation of the sensitizing chromophore, and the metal ion becomes excited to the emission state.
Despite the tremendous amount of work on luminescent lanthanide complexes, only a few complexes have yet been employed for TRLLM, ${ }^{66,67,69,71-75,80,81)}$ and most complexes are used as labeling reagents for proteins. Therefore, we set out to develop responsive luminescent lanthanide probes. There are numerous requirements to be met by luminescent lanthanide complexes for usage in bioimaging with TRLLM, and these include kinetic stability in water, and a sensitizing chromophore unit that generates an efficient antenna effect. Firstly, we designed and synthesized the $\mathrm{Zn}^{2+}$-sensitive luminescent $\mathrm{Tb}^{3+}$ and $\mathrm{Eu}^{3+}$ DTPA-bisamide complexes 7 and $\mathbf{8}$ (Fig. 17) ${ }^{82}$ In the characterization of the new compound 7 , we observed that the time-resolved emission intensity of $\mathrm{Tb}^{3+}$ increased upon addition of $\mathrm{Zn}^{2+}$ between 0 and $1.0 \mathrm{eq}$ in $100 \mathrm{~mm} N$-2-hydroxyethylpiperazine- $N^{\prime}$-2-ethanesulfonic acid (HEPES) buffer ( $\mathrm{pH}$ 7.4). The luminescence emission showed three bands at $490 \mathrm{~nm}, 546 \mathrm{~nm}$, and $587 \mathrm{~nm}$ arising from transitions from the ${ }^{5} \mathrm{D}_{4}$ excited state to the ${ }^{7} \mathrm{~F}_{6},{ }^{7} \mathrm{~F}_{5}$ and

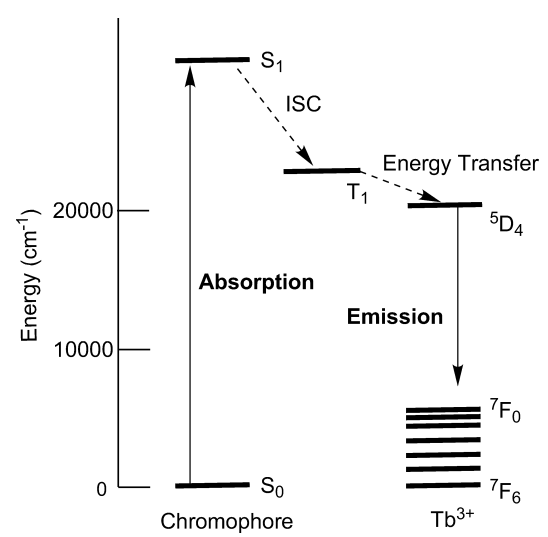

Fig. 15. The General Chromophore-to-Terbium Ion Sensitization Process

Light absorption and lowest-lying singlet excited state $\left(\mathrm{S}_{1}\right)$ formation at the sensitizing chromophore are followed by intersystem crossing (ISC), resulting in population of the triplet excited state $\left(T_{1}\right)$ of the sensitizing chromophore. Subsequent chromophoreto- $\mathrm{Tb}^{3+}$ energy transfer leads to a metal-centered emission, which is derived from transition from the $\mathrm{Tb}^{3+}$-emitting state to the relevant ground states.

a)

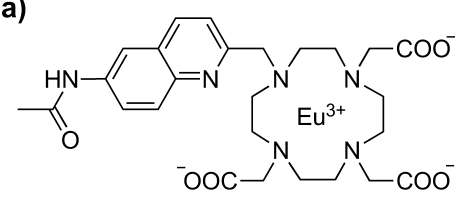

6

b)
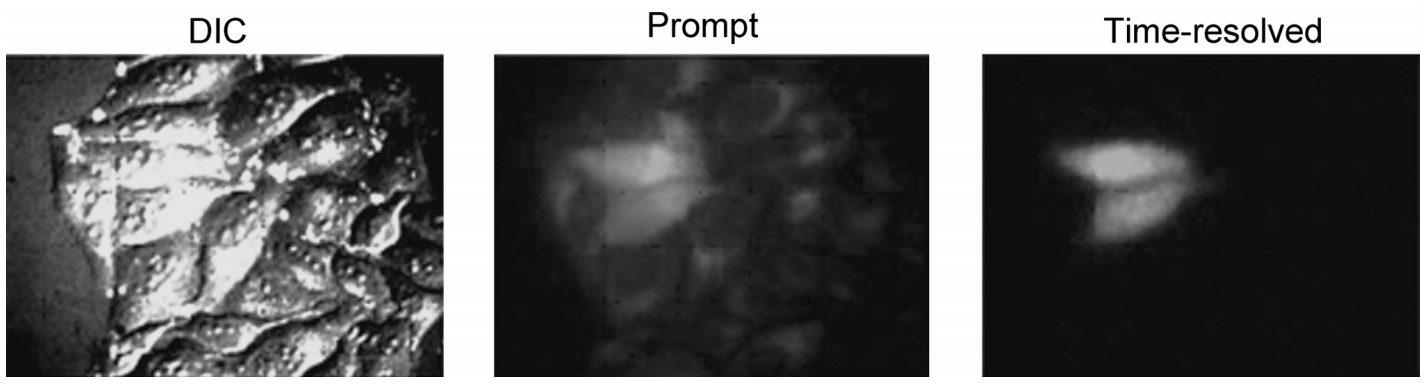

Fig. 16. Time-Resolved, Long-Lived Luminescence Images Provided by Our New TRLLM System

(a) Structure of our newly synthesized $\mathrm{Eu}^{3+}$-polyaminocarboxylate complex incorporating a covalently bound sensitizing chromophore, 6. (b) Two cells were injected with the $\mathrm{Eu}^{3+}$ complex 6 in HBSS buffer. The fluorescence was measured at $617 \pm 37 \mathrm{~nm}$, which is the wavelength range of the Cy3 emission filter, with excitation at $360 \pm 40 \mathrm{~nm}$. Brightfield transmission image (DIC), prompt fluorescence image (Prompt), and time-resolved long-lived luminescence image (Time-resolved) of living cells, including the Eu ${ }^{3+}$ complex-injected cells. 
${ }^{7} \mathrm{~F}_{4}$ ground manifold, respectively (Fig. 15). ${ }^{2,77)}$ The emission intensity of $\mathbf{8}$ upon adding $\mathrm{Zn}^{2+}$ changed in a similar way to that of 7, but with only a sixth of the intensity. The luminescence emission data also revealed very high selectivity for $\mathrm{Zn}^{2+}$ compared with $\mathrm{Ca}^{2+}, \mathrm{Mg}^{2+}$, heavy metal ions $\left(\mathrm{Fe}^{2+}\right.$, $\mathrm{Fe}^{3+}, \mathrm{Cu}^{2+}, \mathrm{Ni}^{2+}, \mathrm{Co}^{2+}$ and $\left.\mathrm{Mn}^{2+}\right)$, and some anions $\left(\mathrm{Cl}^{-}\right.$, carbonate and phosphate). The emission lifetime of 7 after addition of 1.0 eq of $\mathrm{Zn}^{2+}$ was measured in $100 \mathrm{mM}$ HEPES buffer ( $\mathrm{pH} 7.4$ ), and the emission signal showed a single exponential decay with a lifetime of $1.45 \mathrm{~ms}$. Compound 7 showed an apparent dissociation constant $K_{\mathrm{d}}$ for $\mathrm{Zn}^{2+}$ of $2.6 \mathrm{~nm}\left(\mathrm{pH} 7.4,22^{\circ} \mathrm{C}\right)$. The Job plot of the luminescence emission intensity of $\mathrm{Tb}^{3+}$ for complexation between 7 and $\mathrm{Zn}^{2+}$ has a maximum at a mole fraction of 0.5 , which is indicative of the formation of a $1: 1$ complex. Figure 17 shows the proposed conformational change in the presence and absence of $\mathrm{Zn}^{2+}$. The light-conversion process of absorption to emission by energy transfer in compound 7 is also shown. We further investigated the mechanism of luminescence increase of 7 by measuring the effects of $\mathrm{D}_{2} \mathrm{O}$ and $\mathrm{pH}$. We measured the luminescence emission spectra of 7 in $\mathrm{D}_{2} \mathrm{O}$ solution at pD 7.40 (100 mM HEPES buffer) in the presence of various concentrations of $\mathrm{Zn}^{2+}$. The emission spectra in $\mathrm{D}_{2} \mathrm{O}$ solution changed in the same manner as those in $\mathrm{H}_{2} \mathrm{O}$ solution. It can be considered from this result that the increase of the emission intensity of $\mathrm{Zn}^{2+}$ does not mainly because of a change in the direct interaction of water molecules with $\mathrm{Tb}^{3+}$. Further, there was no effect of $\mathrm{H}^{+}$on the emission spectra of 7 between $\mathrm{pH} 3.0$ and 10.0 in the absence of $\mathrm{Zn}^{2+}$. The $\mathrm{p} K_{\mathrm{a}}$ values of TPEN are 7.12, 4.81, 3.30 and $2.88 .^{83)}$ Therefore, it is unlikely that the increase of the emission intensity of 7 generated by the addition of $\mathrm{Zn}^{2+}$ can be ascribed to the cessation of the PeT (photo-induced electron transfer) process, which occurs from the tertiary amine of the TPEN moiety to a pyridyl group. ${ }^{84)}$ Based on these results, the enhancement of the emission intensity of 7 upon $\mathrm{Zn}^{2+}$-binding

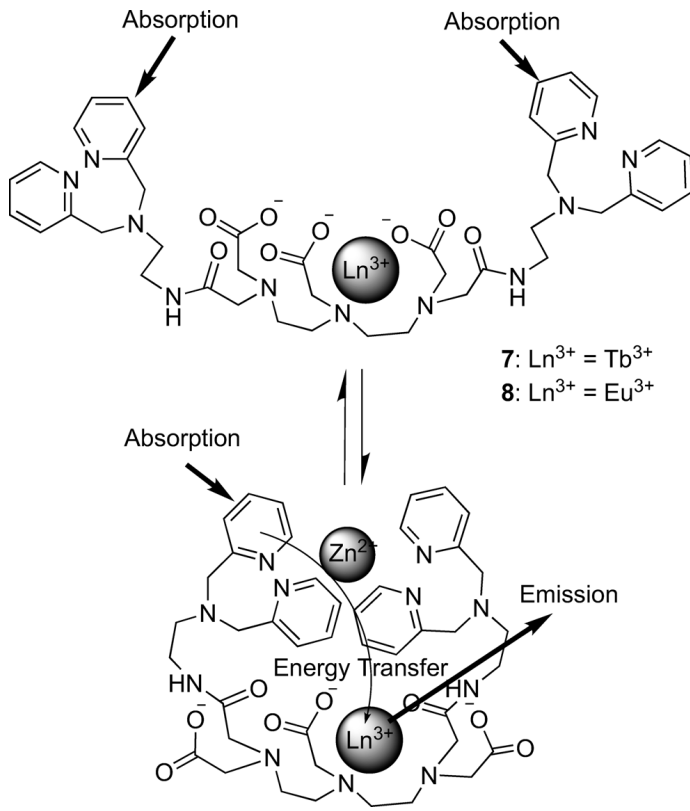

Fig. 17. Schematic of $\mathbf{7}$ or $\mathbf{8}$ Representing the Proposed Conformational Alteration in the Presence and Absence of $\mathrm{Zn}^{2+}$ Ions

The light-conversion process of absorption-energy transfer-emission permitted by 7 or $\mathbf{8}$ is also represented. appears to be the result of efficient intramolecular energy transfer from the pyridyl group to the $\mathrm{Tb}^{3+}$ ion. This simple sensor switch for $\mathrm{Zn}^{2+}$, which serves as both a chromophore and $\mathrm{Zn}^{2+}$ receptor, should be useful for the further development of $\mathrm{Zn}^{2+}$ sensors. Furthermore, it would be desirable to move the excitation wavelength towards the visible region to reduce the phototoxicity of the excitation light for biological samples and to ensure compatibility with the optics of standard fluorescence microscopes. ${ }^{65)}$ Therefore, we designed and synthesized a novel $\mathrm{Zn}^{2+}$-sensitive luminescent $\mathrm{Eu}^{3+}$ complex 9, with a longer excitation wavelength for biological applications, without loss of the high selectivity and high affinity for $\mathrm{Zn}^{2+}$ (Fig. 18). ${ }^{85)}$ The design of 9 was based on complexation of $\mathrm{Eu}^{3+}$-DTPA complex and a quinoline-containing TPEN-based ligand for $\mathrm{Zn}^{2+}$. The quinoline chromophore was selected as an antenna and a ligand, because quinoline has a longer excitation wavelength $(>300 \mathrm{~nm})$ than pyridine and can coordinate to metal ion. In the structure of 9, the quinolyl chromophore is fixed close to the $\mathrm{Eu}^{3+}$ ion, allowing it to function efficiently as an antenna. Upon complexation with $\mathrm{Zn}^{2+}$, compound 9 exhibits strong, long-lived luminescence of the order of milliseconds, and it also offers a large Stoke's shift $(>250 \mathrm{~nm})$, high water-solubility, and high selectivity for $\mathrm{Zn}^{2+}$. i.e., complex 9 in aqueous solution was characterized by a luminescence spectrum with a delay time of $0.05 \mathrm{~ms}$, and the time-resolved luminescence emission intensity of 9 increased significantly ( 8.5 fold) upon addition of $1.0 \mathrm{eq}$ of $\mathrm{Zn}^{2+}$, with a large Stoke's shift of $>250 \mathrm{~nm}$ (Fig. 19). The emission intensity remained at a plateau in the presence of an excess of $\mathrm{Zn}^{2+}$. The luminescence emission displayed three bands at 579, 593, and $614 \mathrm{~nm}$, corresponding to transitions from the ${ }^{5} \mathrm{D}_{0}$ excited state to the ${ }^{7} \mathrm{~F}_{0},{ }^{7} \mathrm{~F}_{1}$, and ${ }^{7} \mathrm{~F}_{2}$ ground states, respectively (Fig. $20) .^{2,77)}$ The Job plot using the luminescence emission intensity of $\mathrm{Eu}^{3+}$ at $614 \mathrm{~nm}$ for the complex of 9 and $\mathrm{Zn}^{2+}$ indicated the presence of the $1: 1$ complex. The luminescence quantum yield $(\Phi)$ was $0.9 \%$ before addition of $\mathrm{Zn}^{2+}$ and
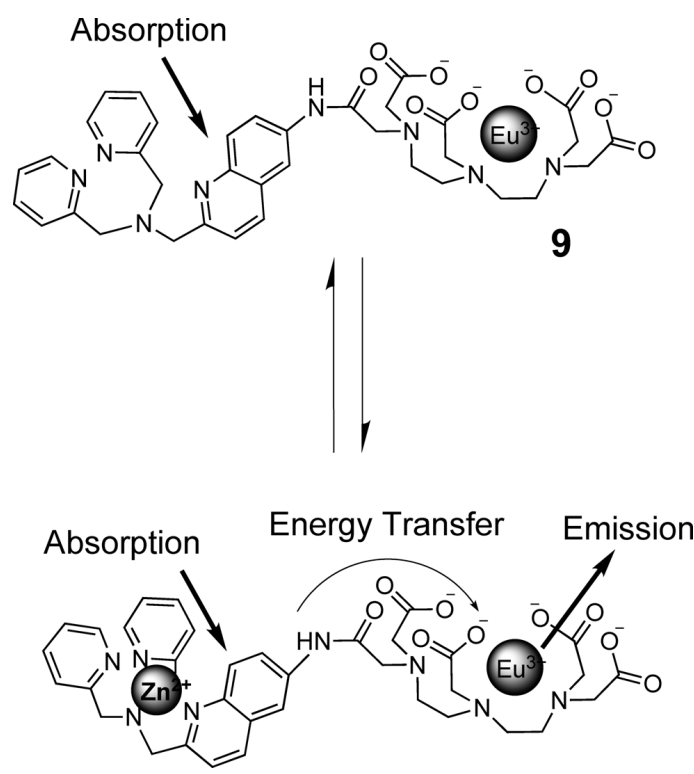

Fig. 18. Schematic of 9 Representing the Proposed Conformation of the Complexation with $\mathrm{Zn}^{2+}$ Ions

The light-conversion process of absorption-energy transfer-emission permitted by 9 is also represented. 


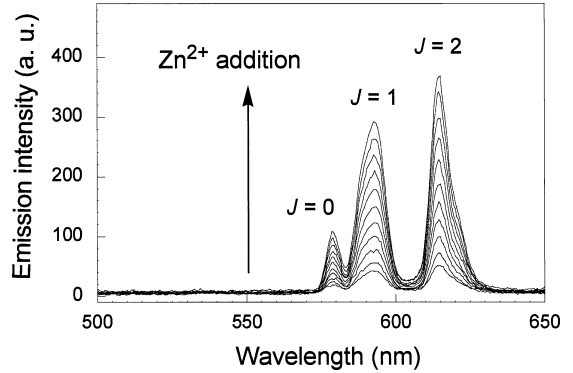

Fig. 19. Time-Resolved Emission Spectra (Excitation at $320 \mathrm{~nm}$ ) of 9 $(50 \mu \mathrm{M})$ in the Presence of Various Concentrations of $\mathrm{Zn}^{2+}: 0,0.1,0.2,0.3$, $0.4,0.5,0.6,0.7,0.8,0.9,1.0$ eq of $\mathrm{Zn}^{2+}$ with Respect to 9

These spectra were measured at $\mathrm{pH} 7.4\left(100 \mathrm{~mm}\right.$ HEPES buffer) and $22^{\circ} \mathrm{C}$ using a delay time of $0.05 \mathrm{~ms}$ and a gate time of $1.00 \mathrm{~ms}$. The bands arise from ${ }^{5} \mathrm{D}_{0} \rightarrow{ }^{7} \mathrm{~F}_{J}$ transitions; the $J$ values of the bands are labeled.

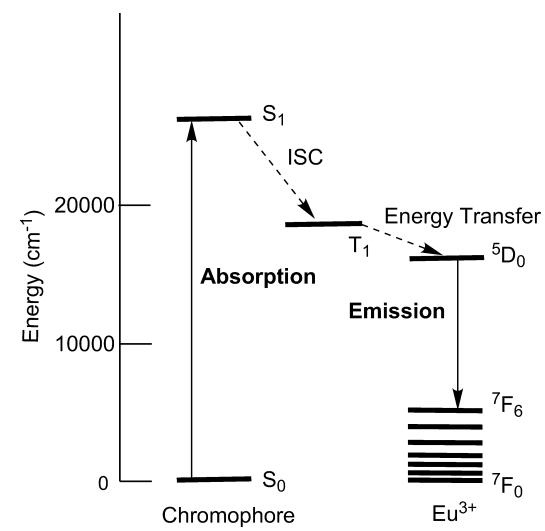

Fig. 20. The General Chromophore-to-Europium Ion Sensitization Process

Light absorption and lowest-lying singlet excited state $\left(\mathrm{S}_{1}\right)$ formation at the sensitizing chromophore are followed by intersystem crossing (ISC), resulting in population of the triplet excited state $\left(T_{1}\right)$ of the sensitizing chromophore. Subsequent chromophoreto-Eu ${ }^{3+}$ energy transfer leads to a metal-centered emission, which is derived from transition from the $\mathrm{Eu}^{3+}$-emitting state to the relevant ground states.

was increased 8.2 -fold to $7.4 \%$ by $\mathrm{Zn}^{2+}$ addition, under airequilibrated conditions. Further, the binding affinity for $\mathrm{Zn}^{2+}$ was assessed by using the luminescence intensity, and the apparent dissociation constant $K_{\mathrm{d}}$ for $\mathrm{Zn}^{2+}$ was calculated to be $59 \mathrm{~nm}$. Measurements of the decay rate constants of the $\mathrm{Eu}^{3+}$ excited state were carried out in both $\mathrm{H}_{2} \mathrm{O}$ and $\mathrm{D}_{2} \mathrm{O}$, in the absence and in the presence of $\mathrm{Zn}^{2+}$. The luminescence lifetimes of 9 were found to be 0.52 (without $\mathrm{Zn}^{2+}$ ) and 0.58 (with $\mathrm{Zn}^{2+}$ ) $\mathrm{ms}$ in $\mathrm{H}_{2} \mathrm{O}\left(\tau_{\mathrm{H}_{\mathrm{O}} \mathrm{O}}\right)$, and 2.03 (without $\mathrm{Zn}^{2+}$ ) and 2.23 (with $\left.\mathrm{Zn}^{2+}\right) \mathrm{ms}$ in $\mathrm{D}_{2} \mathrm{O}\left(\tau_{\mathrm{D}_{2} \mathrm{O}}\right)$. These values indicated that the numbers of coordinated water molecules ( $q$ values) at the metal center were 1.42 and 1.22 , respectively. ${ }^{86)}$ Thus, the lanthanide hydration state was hardly affected by the addition of $\mathrm{Zn}^{2+}$. Therefore, it can be considered that the increase of the emission intensity caused by $\mathrm{Zn}^{2+}$ addition was not due to a change in the direct interaction of water molecules with $\mathrm{Eu}^{3+}$. The luminescence emission intensity of 9 at $614 \mathrm{~nm}$ was examined at various $\mathrm{pH}$ values with excitation at $320 \mathrm{~nm}$. There was almost no effect of $\mathrm{H}^{+}$on the emission spectrum of 9 between $\mathrm{pH} 3.6$ and 8.8 either in the presence or in the absence of $\mathrm{Zn}^{2+}$. Thus, the luminescence emission intensity of 9 is stable at around physiological $\mathrm{pH}$. We believe that this $\mathrm{pH}$ stability of the luminescence is one of the key advantages of $\mathbf{9}$. In addition, the tertiary amine of $\mathbf{9}$ can
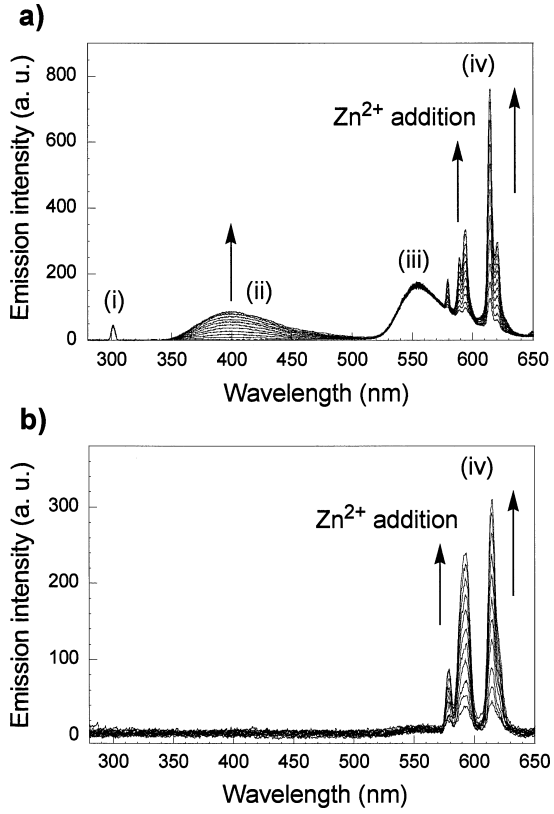

Fig. 21. Emission Spectra of $\mathbf{9}(50 \mu \mathrm{M})$ without (a) and with (b) Time Resolution in the Presence of Various Concentrations of $\mathrm{Zn}^{2+}: 0,0.1,0.2,0.3$, $0.4,0.5,0.6,0.7,0.8,0.9$, and 1.0 eq of $\mathrm{Zn}^{2+}$ with Respect to 9 (Excitation at $300 \mathrm{~nm}$, Respectively)

Both spectra were measured in $100 \mathrm{~mm}$ HEPES buffer containing $1 \mu \mathrm{m}$ rhodamine $6 \mathrm{G}$ as a chromophore to provide artificial background fluorescence at $\mathrm{pH} 7.4$ and $22^{\circ} \mathrm{C}$. The emission spectra (a) were measured with a Hitachi F4500, and the time-resolved emission spectra (b) were measured using a delay time of $0.05 \mathrm{~ms}$ and a gate time of $1.00 \mathrm{~ms}$ with a Perkin-Elmer LS-50B. Bands can be assigned to (i) scattered excitation light, (ii) the fluorescence of the quinolyl chromophore of 9, (iii) the fluorescence of rhodamine $6 \mathrm{G}$, and (iv) the long-lived luminescence of 9 .

be protonated at around $\mathrm{pH} 3.6$, because tris(2-pyridylmethyl)amine (TPA) has $\mathrm{p} K_{\mathrm{a}}$ values of $6.10,4.28$, and 4.29. ${ }^{83)}$ This finding of insensitivity to lower $\mathrm{pH}$ means that the luminescence augmentation was not due to cessation of PeT from the tertiary amine, as was also the case for compound 7. Luminescence emission enhancement of 9 was not observed upon addition of $100 \mathrm{~mm} \mathrm{Na}^{+}$or $\mathrm{K}^{+}, 5 \mathrm{~mm} \mathrm{Ca}^{+}$or $\mathrm{Mg}^{2+}$, or $50 \mu \mathrm{M}$ various heavy metal ions, except for $\mathrm{Cd}^{2+}$. Thus, $\mathrm{Na}^{+}, \mathrm{K}^{+}, \mathrm{Ca}^{2+}$, and $\mathrm{Mg}^{2+}$, which exist at high concentrations in biological systems, did not enhance the luminescence intensity of $\mathbf{9}$. To explore further the utility of the long luminescence lifetime of $\mathbf{9}$, we tested whether long-lived luminescence could be well distinguished from the short-lived background fluorescence and scattered light. Figure 21 presents the emission spectra of a solution of 9 together with $1 \mu \mathrm{M}$ rhodamine $6 \mathrm{G}$ as an artificial short-lived background, without or with a time resolution process. There are three fluorescence peaks in Fig. 21a due to scattered light (300 nm), the increased fluorescence of the quinoline moiety (around $400 \mathrm{~nm}$ ), and the fluorescence of rhodamine 6G (around $550 \mathrm{~nm}$ ). Among them, rhodamine $6 \mathrm{G}$ fluorescence can directly interfere with $\mathrm{Eu}^{3+}$ luminescence. However, the longlived luminescence detection of $\mathbf{9}$ was not affected at all by these three peaks. Thus, the luminescence of $\mathbf{9}$ should be largely free from experimental artifacts when measured with a time-resolution technique.

Compound 9 has a sufficiently long excitation wavelength for fluorescence microscopy, and is suitable for fluorescence microscopic measurements of $\mathrm{Zn}^{2+}$ concentration in living cells. We examined the application of 9 to cultured living 
Intensity

a)

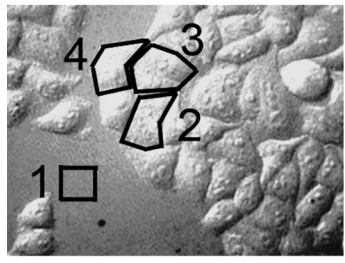

b)

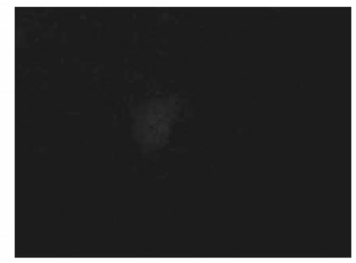

c)

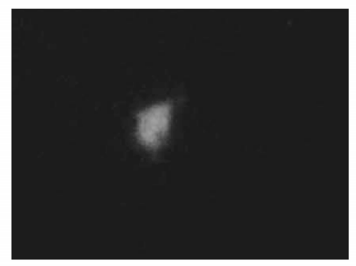

d)

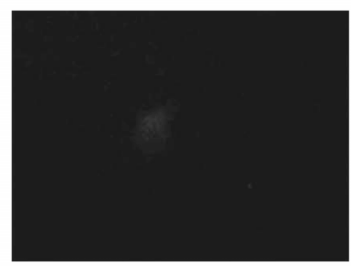

500

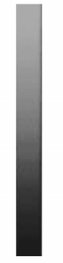

80

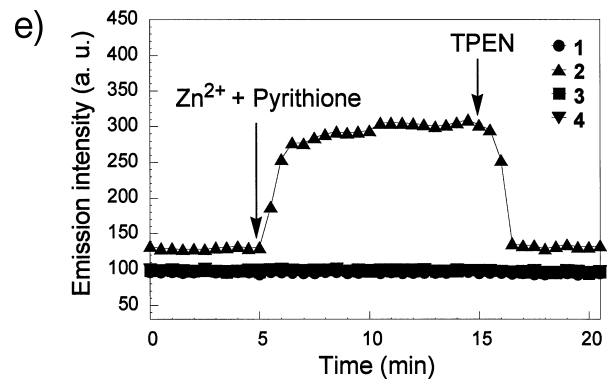

Fig. 22. Time-Resolved Long-Lived Luminescence Imaging of Intracellular $\mathrm{Zn}^{2+}$ in Living HeLa Cells

The luminescence at $617 \pm 37 \mathrm{~nm}$, excited at $360 \pm 40 \mathrm{~nm}$, was measured at $30 \mathrm{~s}$ intervals. The time-resolved long-lived luminescence images were measured with our TRLLM system using a delay time of $70 \mu \mathrm{s}$ and a gate time of $808 \mu \mathrm{s}$. The HeLa cell in HBSS buffer was injected with the solution of 9. (a) Bright-field transmission image ( 0 min). (b) Time-resolved long-lived luminescence image of (a) $(0 \mathrm{~min})$. (c) Time-resolved long-lived luminescence image ( 7 min) following addition of $5 \mu \mathrm{M}$ pyrithione (zinc ionophore) and $50 \mu \mathrm{M} \mathrm{ZnSO}$ to the medium at $5 \mathrm{~min}$. (d) Time-resolved long-lived luminescence image ( $17 \mathrm{~min})$ following addition of $100 \mu \mathrm{M}$ TPEN to the medium at $15 \mathrm{~min}$. Time-resolved long-lived luminescence images $(\mathrm{b}-\mathrm{d})$ correspond to the luminescence intensity data in (e), which shows the average intensity of the corresponding area or cell area in (a) (1, extracellular region; 2, intracellular region of the injected cell; 3,4 , intracellular regions of noninjected cells).

HeLa cells by using our TRLLM system (Fig. 22). ${ }^{65)}$ Optical parameters were as follows: the fluorescence microscope had an optical window centered at $617 \pm 37 \mathrm{~nm}$ for the emission due to $\mathrm{Eu}^{3+}$-based luminescence excited at $360 \pm 40 \mathrm{~nm}$. The delay time, prior to initiation of counting, and the gate time, during which counting takes place, were set at $70 \mu \mathrm{s}$ and $808 \mu$ s, respectively. Compound 9 was injected into a single cultured HeLa cell in the central part of the field of view in Fig. 22a. A prompt increase of intracellular luminescence was induced when $\mathrm{Zn}^{2+}(50 \mu \mathrm{M})$ and pyrithione (2-mercaptopyridine $N$-oxide, $5 \mu \mathrm{M}$ ), which is a zinc-selective ionophore, were added to the medium at $5 \mathrm{~min}$ (Fig. 22c). Further, the luminescence intensity decreased immediately upon extracellular addition of the cell-membrane-permeable chelator TPEN $(100 \mu \mathrm{M})$ at $15 \mathrm{~min}$ (Fig. 22d). Clear images of intracellular $\mathrm{Zn}^{2+}$ concentration changes were obtained with the TRLLM system (Fig. 22e). To explore further the utility of TRLLM, we tested whether long-lived luminescence could be well distinguished from the short-lived fluorescence of rhodamine $6 \mathrm{G}$ as an artificial source of shortlived background fluorescence. Rhodamine $6 \mathrm{G}$ fluorescence directly interferes with $\mathrm{Eu}^{3+}$ luminescence because rhodamine $6 \mathrm{G}$ has similar excitation and emission wavelength ranges to those of $\mathbf{9}$. We found that the time-resolved longlived luminescence images were not affected at all by rhodamine 6G fluorescence, i.e., 9 could be used to monitor changes of intracellular $\mathrm{Zn}^{2+}$ concentration even in cells stained with rhodamine $6 \mathrm{G}$ (data not shown). ${ }^{65)}$

\section{Conclusion and Perspectives}

Multi-modality molecular imaging is currently attracting much interest, because a single imaging modality can not provide complete information on targeted molecules. ${ }^{44)}$ For example, optical fluorescence imaging is difficult at more than a few millimeters in depth within a tissue specimen, and MRI has high resolution but low sensitivity. At presnt, combined MRI/optical imaging is one of the best-developed techniques of dual-modality imaging, and has been employed in biomedical research and clinical practice. ${ }^{87)}$ Indeed, MRI/optical probes have been increasingly developed in recent years. We have successfully designed and synthesized various responsive lanthanide-based MRI and luminescent probes for bioimaging. In the development of MRI contrast agents, effective strategies to increase or decrease the $r_{1}$ relaxivity include making use of increased hydration number, fast water exchange, slower molecular tumbling rate, and second-sphere effects. Therefore, through judicious molecular design, high-relaxivity complexes with highly targeted functions can be realized. However, responsive MRI contrast agents for monitoring biomolecules in vivo have only recently begun to appear in the literature, and only a few have been applied in vivo. Therefore, while advances in technology have made MR imaging a modality of choice, the development of highly sensitive and multipurpose MR contrast agents is still needed. For example, there have recently been advances in the design and synthesis of cell-penetrating and receptor-targeted MR imaging agents. ${ }^{88-90)}$ On the other hand, in the case of luminescent lanthanide complexes, sensors for a targeted analyte can be designed by rationally manipulating the parameters that influence the luminescence of lanthanide complexes, such as varying the number of innersphere water molecules, the distance separating the antenna from the lanthanide ion, the energies of excited states of the antenna, and PeT switches. Thus, a wide variety of analytes can be detected, including $\mathrm{pH}$, ions, reactive oxygen species, and enzymes. ${ }^{91)}$ However, in designing luminescent lan- 


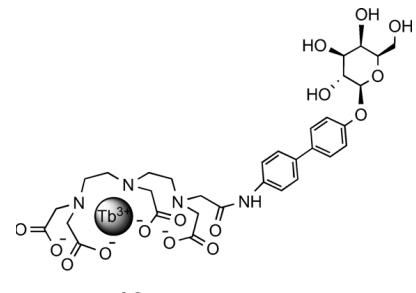

10

Fig. 23. Structure of Luminescent $\mathrm{Tb}^{3+}$ Complex 10, Which Is a Homologue of the $\mathrm{Gd}^{3+}$ Complex 3

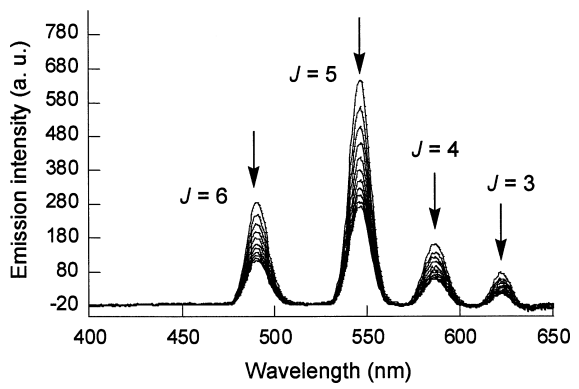

Fig. 24. Time-Resolved Emission Spectra (Excitation at $280 \mathrm{~nm}$ ) of $\mathbf{1 0}$ $(50 \mu \mathrm{M})$ after the Addition of $\beta$-Galactosidase (113 nм) in $100 \mathrm{~mm}$ HEPES Buffer (pH 7.4) at $25^{\circ} \mathrm{C}$

Time-resolved emission spectra of $\mathbf{1 0}$ were measured every $10 \mathrm{~min}(0-100 \mathrm{~min})$ after addition of $\beta$-galactosidase. The bands arise from ${ }^{5} \mathrm{D}_{4} \rightarrow{ }^{7} \mathrm{~F}_{J}$ transitions; the $J$ values of the bands are labeled.

thanide sensors for cellular imaging, chemists should keep in mind that for practical applications, these complexes also must be able to penetrate cells. ${ }^{5,65,92)}$ Unfortunately, little is yet known about how lanthanide complexes penetrate cells. Until this problem is resolved, the practical utility of lanthanide complexes as intracellular probes will remain limited. Further, it is also necessary to develop sensors with a longer excitation wavelength in the visible region in order to reduce phototoxicity for biological applications. ${ }^{93)}$ Thus, the design of appropriate multi-modal imaging probes is the key to further advances in multi-modality bioimaging, and it may be particularly useful to develop MRI/optical multi-modal imaging probes. For example, compound 10, which is a homologue of 3, was relatively brightly luminescent (Fig. 23), and the time-resolved luminescence spectra of $\mathbf{1 0}$ with a delay time of $50 \mu \mathrm{s}$ displayed four bands (490, 545, 586, $622 \mathrm{~nm}$ ), arising from transitions from the emissive ${ }^{5} \mathrm{D}_{4}$ state to the ground-state manifolds ${ }^{7} \mathrm{~F}_{6},{ }^{7} \mathrm{~F}_{5},{ }^{7} \mathrm{~F}_{4}$, and ${ }^{7} \mathrm{~F}_{3}$, respectively (Fig. 15). $\left.{ }^{41}\right) \mathrm{The}^{\mathrm{Tb}^{3+}}$ ion possesses the same charge as $\mathrm{Gd}^{3+}$, as well as similar ionic radius and coordination chemistry. Further, addition of $\beta$-galactosidase to an aqueous solution of $\mathbf{1 0}$ resulted in an about $43 \%$ decrease in the luminescence of $\mathrm{Tb}^{3+}$ at $545 \mathrm{~nm}$ as shown in Fig. 24. On the basis of the above results, the biphenyl substituent, which is an albumin-binding group, also serves as a sensitizing chromophore for $\mathrm{Tb}^{3+}$ in the luminescent $\mathrm{Tb}^{3+}$ complex $\mathbf{1 0}$, and a mixture of $\mathbf{3}$ and $\mathbf{1 0}$ could potentially be a multi-modal imaging probe. Thus, the development of multi-modal imaging probes for multi-modality molecular imaging certainly seems feasible, through the application of interdisciplinary approaches.

Acknowledgments All the results described in this review were obtained at Graduate School of Pharmaceutical Sciences, The University of Tokyo, and Department of Internal Medicine, University of Texas South- western Medical Center. I would like to express sincere appreciation to Professor Tetsuo Nagano, Professor Kazuya Kikuchi, Professor Thomas Kodadek, and Professor A. Dean Sherry for their helpful, continuous advice and support. The research reviewed in this paper was possible only with the contributions of all the co-workers and collaborators whose names are acknowledged in the publications from our laboratory cited here. These studies were supported by a Grant-in Aid for Young Scientists (A), a grant for challenging Exploratory Research, Research Activity start-up, and a JSPS Fellowship from the Ministry of Education, Culture, Sports, Science and Technology of Japan, as well as grants from the Mochida Memorial Foundation for Medical and Pharmaceutical Research and Sankyo Foundation of Life Science.

\section{References}

1) Thunus L., Lejeune R., Coord. Chem. Rev., 184, 125-155 (1999).

2) Eliseeva S. V., Bünzli J. C. G., Chem. Soc. Rev., 39, 189-227 (2010).

3) Thibon A., Pierre V. C., Anal. Bioanal. Chem., 394, 107-120 (2009).

4) De Leon-Rodriguez L. M., Lubag A. J. M., Malloy C. R., Martinez G. V., Gillies R. J., Sherry A. D., Acc. Chem. Res., 42, 948-957 (2009).

5) New E. J., Parker D., Smith D. G., Walton J. W., Curr. Opin. Chem. Biol., 14, 238-246 (2010).

6) Caravan P., Ellison J. J., McMurry T. J., Lauffer R. B., Chem. Rev., 99, 2293-2352 (1999)

7) Merbach A. E., Tóth É., "The Chemistry of Contrast Agents in Medical Magnetic Resonance Imaging," Wiley, New York, 2001.

8) Comblin V., Gilsoul D., Hermann M., Humblet V., Jacques V., Mesbahi M., Sauvage C., Desreux J. F., Coord. Chem. Rev., 185-186, 451470 (1999).

9) Botta M., Eur. J. Inorg. Chem., 2000, 399-407 (2000).

10) Aime S., Botta M., Fasano M., Terreno E., Acc. Chem. Res., 32, 941 949 (1999).

11) Louie A. Y., Hüber M. M., Ahrens E. T., Rothbächer U., Moats R., Jacobs R. E., Fraser S. E., Meade T. J., Nat. Biotechnol., 18, 321-325 (2000).

12) Li W., Fraser S. E., Meade T. J., J. Am. Chem. Soc., 121, 1413-1414 (1999).

13) Zhang S., Wu K., Sherry A. D., Angew. Chem. Int. Ed., 38, $3192-$ 3194 (1999).

14) Aime S., Botta M., Gianolio E., Terreno E., Angew. Chem. Int. Ed., 39 , $747-750$ (2000)

15) Trokowski R., Zhang S., Sherry A. D., Bioconjugate Chem., 15, 1431-1440 (2004).

16) Högemann D., Basilion J. P., Eur. J. Nucl. Med., 29, 400- 408 (2002).

17) Weissleder R., Moore A., Mahmood U., Bhorade R., Benveniste H., Chiocca E. A., Basilion J. P., Nat. Med., 6, 351-354 (2000).

18) Spergel D. J., Krüth U., Shimshek D. R., Sprengel R., Seeburg P. H., Prog. Neurobiol., 63, 673-686 (2001).

19) Hanaoka K., Kikuchi K., Urano Y., Nagano T., J. Chem. Soc., Perkin Trans. 2, 2001, 1840-1843 (2001).

20) Vallee B. L., Falchuk K. H., Physiol. Rev., 73, 79-118 (1993).

21) Berg J. M., Shi Y., Science, 271, 1081-1085 (1996).

22) Frederickson C. J., Int. Rev. Neurobiol., 31, 145-238 (1989)

23) Choi D. W., Koh J. Y., Annu. Rev. Neurosci., 21, 347-375 (1998).

24) Hirano T., Kikuchi K., Urano Y., Higuchi T., Nagano T., J. Am. Chem Soc., 122, 12399-12400 (2000).

25) Cuajungco M. P., Lees G. J., Brain Res., 799, 97-107 (1998).

26) Sakamoto S., Fujita M., Kim K., Yamaguchi K., Tetrahedron, 56, 955-964 (2000).

27) Sakamoto S., Yoshizawa M., Kusukawa T., Fujita M., Yamaguchi K., Org. Lett., 3, 1601-1604 (2001).

28) Yamanoi Y., Sakamoto Y., Kusukawa T., Fujita M., Sakamoto S., Yamaguchi K., J. Am. Chem. Soc., 123, 980-981 (2001).

29) Hanaoka K., Kikuchi K., Urano Y., Narazaki M., Yokawa T., Sakamoto S., Yamaguchi K., Nagano T., Chem. Biol., 9, 1027-1032 (2002).

30) Zhang X., Lovejoy K. S., Jasanoff A., Lippard S. J., Proc. Natl. Acad. Sci. U.S.A., 104, 10780-10785 (2007).

31) Major J. L., Parigi G., Luchinat C., Meade T. J., Proc. Natl. Acad. Sci. U.S.A., 104, 13881-13886 (2007).

32) Esqueda A. C., López J. A., Andreu-de-Riquer G., Alvarado-Monzón J. C., Ratnakar J., Lubag A. J. M., Sherry A. D., León-Rodríguez L. M. D., J. Am. Chem. Soc., 131, 11387-11391 (2009).

33) Caravan P., Cloutier N. J., Greenfield M. T., McDermid S. A., Dunham S. U., Bulte J. W. M., Amedio J. C. Jr., Looby R. J., Supkowski R. M., 
Horrocks, W. D. Jr., McMurry T. J., Lauffer R. B., J. Am. Chem. Soc., 124, 3152-3162 (2002).

34) Aime S., Gianolio E., Terreno E., Giovenzana G. B., Pagliarin R., Sisti M., Palmisano G., Botta M., Lowe M. P., Parker D., J. Biol. Inorg. Chem., 5, 488-497 (2000).

35) Aime S., Botta M., Crich S. G., Giovenzana G. B., Pagliarin R., Piccinini M., Sisti M., Terreno E., J. Biol. Inorg. Chem., 2, 470- 479 (1997)

36) Lowe M. P., Aust. J. Chem., 55, 551-556 (2002).

37) Lauffer R. B., McMurry T. J., Dunham S. O., Scott D. M., Parmelee D. J., Dumas S., PCT Int. Appl. WO 9736619 (1997).

38) Nivorozhkin A. L., Kolodziej A. F., Caravan P., Greenfield M. T., Lauffer R. B., McMurry T. J., Angew. Chem. Int. Ed., 40, 2903-2906 (2001).

39) De León-Rodríguez L. M., Ortiz A., Weiner A. L., Zhang S., Kovacs Z., Kodadek T., Sherry A. D., J. Am. Chem. Soc., 124, 3514-3515 (2002).

40) Rodríguez E., Nilges M., Weissleder R., Chen J. W., J. Am. Chem. Soc., 132, 168-177 (2010).

41) Hanaoka K., Kikuchi K., Terai T., Komatsu T., Nagano T., Chem. Eur. J., 14, 987—995 (2008).

42) Aime S., Chiaussa M., Digilio G., Gianolio E., Terreno E., J. Biol. Inorg. Chem., 4, 766-774 (1999).

43) Gore J. C., Yankeelov T. E., Peterson T. E., Avison M. J., J. Nucl. Med., 50, 999-1007 (2009).

44) Weissleder R., Pittet M. J., Nature (London), 452, 580 - 589 (2008).

45) Sipkins D. A., Cheresh D. A., Kazemi M. R., Nevin L. M., Bednarski M. D., Li K. C. P., Nat. Med., 4, 623-626 (1998).

46) Tiefenauer L. X., Kühne G., Andres R. Y., Bioconjugate Chem., 4, 347-352 (1993)

47) Marecos E., Weissleder R., Bogdanov Jr. A., Bioconjugate Chem., 9, 184-191 (1998)

48) Benedetto S., Pulito R., Crich S. G., Tarone G., Aime S., Silengo L., Hamm J., Magn. Reson. Med., 56, 711-716 (2006).

49) Huh Y. M., Jun Y., Song H. T., Kim S., Choi J., Lee J. H., Yoon S., Kim K. S., Shin J. S., Suh J. S., Cheon J., J. Am. Chem. Soc., 127, 12387-12391 (2005).

50) Weinmann H. J., Ebert W., Misselwitz B., Schmitt-Willich H., Eur. J. Radiol., 46, 33- 44 (2003).

51) Shahbazi-Gahrouei D., Williams M., Rizvi S., Allen B. J., J. Magn. Reson. Imaging, 14, 169-174 (2001).

52) Konda S. D., Aref M., Brechbiel M., Wiener E. C., Invest. Radiol., 35, $50-57$ (2000).

53) Montet X., Weissleder R., Josephson L., Bioconjugate Chem., 17, 905-911 (2006).

54) Högemann D., Josephson L., Weissleder R., Basilion J. P., Bioconjugate Chem., 11, 941-946 (2000).

55) Anelli P. L., Bertini I., Fragai M., Lattuada L., Luchinat C., Parigi G., Eur. J. Inorg. Chem., 2000, 625-630 (2000).

56) Wolf M., Hull W. E., Mier W., Heiland S., Bauder-Wüst U., Kinscherf R., Haberkorn U., Eisenhut M., J. Med. Chem., 50, 139-148 (2007).

57) Leuschner C., Kumar C. SSR, Hansel W., Soboyejo W., Zhou J., Hormes J., Breast Cancer Res. Treat., 99, 163-176 (2006).

58) Lee J. H., Huh Y. M., Jun Y., Seo J., Jang J., Song H. T., Kim S., Cho E. J., Yoon H. G., Suh J. S., Cheon J., Nat. Med., 13, 95-99 (2007).

59) Hanaoka K., Lubag A. J. M., Castillo-Muzquiz A., Kodadek T., Sherry A. D., Magn. Reson. Imaging, 26, 608-617 (2008).

60) Ahrens E. T., Rothbächer U., Jacobs R. E., Fraser S. E., Proc. Natl. Acad. Sci. U.S.A., 95, 8443-8448 (1998).

61) Backer M. V., Gaynutdinov T. I., Patel V., Bandyopadhyaya A. K., Thirumamagal B. T. S., Tjarks W., Barth R. F., Claffey K., Backer J. M., Mol. Cancer Ther., 4, 1423-1429 (2005).

62) Hirano T., Kikuchi K., Urano Y., Nagano T., J. Am. Chem. Soc., 124
$6555-6562$ (2002).

63) Izumi S., Urano Y., Hanaoka K., Terai T., Nagano T., J. Am. Chem. Soc., 131, 10189-10200 (2009).

64) Suhling K., French P. M. W., Phillips D., Photochem. Photobiol. Sci., 4, 13-22 (2005).

65) Hanaoka K., Kikuchi K., Kobayashi S., Nagano T., J. Am. Chem. Soc., 129, 13502-13509 (2007).

66) Weibel N., Charbonnière L. J., Guardigli M., Roda A., Ziessel R., J. Am. Chem. Soc., 126, 4888- 4896 (2004).

67) Marriott G., Heidecker M., Diamandis E. P., Marriott Y. Y., Biophys. $J ., 67,957-965$ (1994)

68) Marriott G., Clegg R. M., Arndt-Jovin D. J., Jovin T. M., Biophys. J., 60, 1374-1387 (1991)

69) Phimphivong S., Saavedra S. S., Bioconjugate Chem., 9, 350-357 (1998).

70) de Haas R. R., van Gijlswijk R. P. M., van der Tol E. B., Veuskens J., van Gijssel H. E., Tijdens R. B., Bonnet J., Verwoerd N. P., Tanke H. J., J. Histochem. Cytochem., 47, 183-196 (1999).

71) Vereb G., Jares-Erijman E., Selvin P. R., Jovin T. M., Biophys. J., 74, 2210-2222 (1998)

72) Seveus L., Väisälä M., Syrjänen S., Sandberg M., Kuusisto A., Harju R., Salo J., Hemmlilä I., Kojola H., Soini E., Cytometry, 13, 329-338 (1992).

73) Sevéus L., Väisälä M., Hemmilä I., Kojola H., Roomans G. M., Soini E., Microsc. Res. Tech., 28, 149-154 (1994).

74) Beeby A., Botchway S. W., Clarkson I. M., Faulkner S., Parker A. W., Parker D., Williams J. A. G., J. Photochem. Photobiol. B, 57, 83-90 (2000).

75) Connally R., Veal D., Piper J., Microsc. Res. Tech., 64, 312-322 (2004).

76) Choppin G. R., Petermann D. R., Coord. Chem. Rev., 174, 283-299 (1998).

77) Binnemanns K., Chem. Rev., 109, 4283-4374 (2009).

78) Hemmilä I., Webb S., Drug Discovery Today, 2, 373-381 (1997).

79) Parker D., Williams J. A. G., J. Chem. Soc., Dalton Trans., 1996, 3613-3628 (1996)

80) Song B., Wang G., Tan M., Yuan J., J. Am. Chem. Soc., 128, 13442$13450(2006)$

81) Pandya S., Yu J., Parker D., Dalton Trans., 2006, 2757-2766 (2006).

82) Hanaoka K., Kikuchi K., Kojima H., Urano Y., Nagano T., Angew. Chem. Int. Ed., 42, 2996-2999 (2003).

83) Martell A. E., Smith R. M., NIST Critically Selected Stability Constants of Metal Complexes: NIST Standard Reference Database 46, Version 6.0, 2001

84) Terai T., Kikuchi K., Iwasawa S., Kawabe T., Hirata Y., Urano Y., Nagano T., J. Am. Chem. Soc., 128, 6938-6946 (2006).

85) Hanaoka K., Kikuchi K., Kojima H., Urano Y., Nagano T., J. Am. Chem. Soc., 126, 12470-12476 (2004).

86) Beeby A., Clarkson I. M., Dickins R. S., Faulkner S., Parker D., Royle L., de Sousa A. S., Williams J. A. G., Woods M., J. Chem. Soc., Perkin Trans. 2, 1999, 493-503 (1999).

87) Jennings L. E., Long N. J., Chem. Comm., 2009, 3511-3524 (2009).

88) Major J. L., Meade T. J., Acc. Chem. Res., 42, 893—903 (2009).

89) Caravan P., Acc. Chem. Res., 42, 851—862 (2009).

90) Khemtong C., Kessinger C. W., Gao J., Chem. Commun., 2009, 3497-3510 (2009)

91) Parker D., Coord. Chem. Rev., 205, 109-130 (2000).

92) Poole R. A., Bobba G., Cann M. J., Frias J. C., Parker D., Peacock R. D., Org. Biomol. Chem., 3, 1013-1024 (2005).

93) Yang C., Fu L. M., Wang Y., Zhang J. P., Wong W. T., Ai X. C., Qiao Y. F., Zou B. S., Gui L. L., Angew. Chem. Int. Ed., 43, 5010-5013 (2004). 